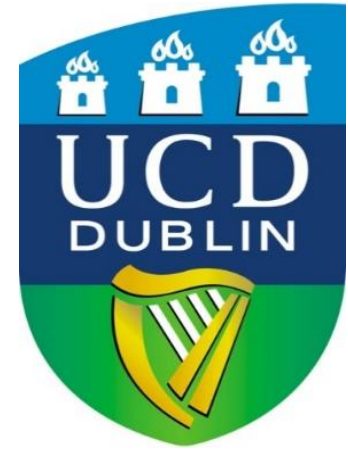

UCD GEARY INSTITUTE FOR PUBLIC POLICY

DISCUSSION PAPER SERIES

\title{
Building Bridges or Breaking Bonds? The Belt and Road Initiative and Foreign Aid Competition
}

\author{
Krishna Chaitanya Vadlamannati \\ School of Politics \& International Relations \\ University College Dublin \\ Yuanxin Li \\ School of Politics \& International Relations \\ University College Dublin \\ Samuel Brazys \\ School of Politics \& International Relations \\ University College Dublin \\ Alexander Dukalskis \\ School of Politics \& International Relations \\ University College Dublin
}

Geary WP2019/06

April 9, 2019

UCD Geary Institute Discussion Papers often represent preliminary work and are circulated to encourage discussion. Citation of such a paper should account for its provisional character. A revised version may be available directly from the author.

Any opinions expressed here are those of the author(s) and not those of UCD Geary Institute. Research published in this series may include views on policy, but the institute itself takes no institutional policy positions 


\begin{abstract}
China's renewed prominence is the most important development in international relations in the $21^{\text {st }}$ century. Despite longstanding rhetoric of its own "peaceful rise", China is increasingly viewed as a long-term strategic competitor, especially in the United States. Foreign aid is one arena where this competition may be playing out. While Western foreign aid principles have emphasized coordination and harmonization, the rise of China as a major development partner has raised the specter of a return to competitive foreign aid practices. Most notably, China's Belt and Road Initiative (BRI), has received a wary reception by some who view it primarily as a geostrategic effort. We test if the $\mathrm{BRI}$ is inducing a competitive foreign aid response by evaluating if countries involved in this initiative are more likely to receive US support for loan packages from the major, Western, multilateral development banks (MDBs). Using an instrumental variable approach, covering 6975 project/loan packages in 16 MDBs from 157 countries during 2013-2018 period, we find that the United States is more likely to vote for MDB packages to countries that have signed on to the BRI, predominantly when the actual amount of Chinese aid flowing to those countries is still low, suggesting the US is competing for "in play" countries.
\end{abstract}

\title{
1. Introduction
}

On Friday October $5^{\text {th }}, 2018$ United States President Donald Trump signed into law H.R. 302, the "FAA Reauthorization Act of 2018" a routine piece of housekeeping legislation to renew the US Federal Aviation Authority. Unceremoniously tacked on to the already brief press release was a clause which noted that the bill also established "a United States International Development Finance Corporation" (IDFC). ${ }^{1}$ On paper, this did little more than consolidate two existing aid agencies, the Overseas Private Investment Corporation (OPIC) and the Development Credit Authority (DCA). However, the move was quickly interpreted as a direct response to an announcement the previous month that China would make $\$ 60$ billion of politically unconditional loans and aid available to African nations. ${ }^{2}$ Interpreting the US move as a counter to this Chinese initiative is plausible given that the Trump administration's plan had previously been to shut down OPIC. ${ }^{3}$ Instead, the bill authorized up to $\$ 60$ billion for the

\footnotetext{
1 https://www.whitehouse.gov/briefings-statements/president-donald-j-trump-signs-h-r-302-law/ accessed 27-10-2018

2 https://www.washingtonpost.com/world/china-pledges-60-billion-in-aid-and-loans-to-africa-nostrings-attached/2018/09/03/a446af2a-af88-11e8-a8104d6b627c3d5d_story.html?noredirect=on\&utm_term=.a35dcfb99ae9 accessed 27-20-2018; https://foreignpolicy.com/2018/10/08/trump-reaches-for-checkbook-diplomacy-to-counter-china/ accessed 27-10-2018.

3 https://www.nytimes.com/2018/10/14/world/asia/donald-trump-foreign-aid-bill.html accessed 27-10-2018
} 
IDFC, echoing a symmetry of the tit-for-tat exchanges that characterized the escalating trade war between the US and China during much of 2018.

Developments like these have fed a broader narrative that China and the US have moved from an era of cooperative engagement to one of strategic rivalry. ${ }^{4}$ Yet scholars have been aware of this impeding systemic shift for some time, and have been examining if and how China is challenging the US-led global order (Foot 2006; Campbell 2008; Schweller and Pu 2011; Khong 2014; Layne 2018). In particular, Chinese foreign aid and development efforts have received increasing scrutiny in terms not only of patterns of allocation and effectiveness (Dreher et al. 2016; Dreher et al. 2017; Dreher et al. 2018a) but also in terms of the extent to which they are challenging or frustrating the efforts of traditional development partners (Hernandez 2017; Swedlund 2017).

On the Chinese side, the most important development is the "Belt and Road Initiative" (BRI). First unveiled in 2013, what later came to be known as the "One Belt, One Road" initiative (OBOR), and then the BRI, has evolved into a massive plan to build, finance and support major land and sea-based economic corridors (or new "silk roads") to link and develop the economies of Eurasia. ${ }^{5}$ While the initiative was originally met with cautious optimism by traditional development organizations, the tone has turned increasingly skeptical and has led to accusations that China is engaging in "debt-trap" politics which has put it at odds with other traditional creditors. ${ }^{6}$

In this paper we examine if patterns of strategic foreign aid politics are evident in the Western response to the BRI. In particular, we consider how the US has responded via multilateral development banks (MDBs) to countries which have embraced the Chinese initiative. Drawing on a rational choice logic, we argue that the strategic response behavior of the US via MDBs to the BRI will depend on the marginal return on investment. As such, we would expect that the US will compete primarily for countries which are targeted by the BRI but where Chinese investment is not yet sufficiently high. Using a novel dataset on the level BRI engagement developed for this paper and an instrumental variable estimation strategy we find evidence that supports this claim.

\footnotetext{
${ }^{4}$ https://www.economist.com/leaders/2018/10/18/the-end-of-engagement accessed 27-10-2018 https://thediplomat.com/2018/08/us-china-relations-from-cooperating-rivals-to-competing-rivals/ accessed 27-10-2018

${ }^{5}$ http://english.gov.cn/news/top_news/2015/04/20/content_281475092566326.htm accessed 27$10-2018$

${ }^{6}$ http://blogs.worldbank.org/trade/three-opportunities-and-three-risks-belt-and-road-initiative accessed 09-12-2018

https://www.hindustantimes.com/world-news/make-no-mistake-pakistan-can-t-use-imf-bailout-topay-off-its-china-debts-warns-us/story-CXNi7T1WVFbYvcMuddBkNM.html accessed 09-122018
} 


\section{The Belt and Road Initiative and the US Response}

Until recently, the overarching aims of Chinese foreign policy in the postMao era could be usefully understood as minimizing perceived internal and regional vulnerabilities (Nathan \& Scobell 2012). More specifically, Beijing organized its foreign policy to achieve, at minimum, the aims of protecting the rule of the Chinese Communist Party (CCP), maintaining high economic growth to ensure social stability, and defending China's territorial integrity including reunification with Hong Kong and Taiwan (Heillman \& Schmidt 2014; Buzan 2014). However, although there were hints of a revisionist foreign policy in preceding years (Schweller \& Pu 2011; Brazys \& Dukalskis 2017), since the rise of Xi Jinping, China's foreign policy has clearly become more assertive and ambitious (Zhang 2015). As Economy (2018: 187) puts it, Xi “...has a stated and demonstrated desire to shape the international system, to use China's power to influence others, and to establish the global rules of the game." The days of the CCP "laying low" in foreign policy are gone (Poh \& Li 2017).

The most publicised initiative in China's reinvigorated foreign policy is the BRI. At its most basic, the BRI is a web of loosely connected economic and infrastructure projects backed by significant Chinese lending. A report published in 2017 suggests that Chinese investments related to the BRI projects have reached $\$ 60$ billion since 2013 and will expand to $\$ 600-800$ billion in total investment through $2022 .^{7}$ However, the size of BRI is hard to measure because it is "a moving target, loosely defined and ever expanding" (Hillman 2018). Moreover, the scope of BRI activities includes not only investment in hard infrastructure, but also soft infrastructure such as trade deals, tourism and other "people-to-people" ties such as education and cultural exchanges (Hillman 2018).

Nevertheless, it can be argued that the BRI is the foundation of China's grand strategy under Xi (Rolland 2017a; Wang 2016). Callahan (2016: 228) sums up the strategy as follows: "to use economic leverage to build a Sino-centric 'community of shared destiny' in Asia, which in turn will make China a normative power that sets the rules of the game for global governance." This is a somewhat more critical characterization than previous interpretations of China's grand strategy which emphasized peaceful rise/development (Buzan 2014), the imperative to modernize without being perceived as threatening by others (Goldstein 2005), or the lack of a grand strategy all together while focusing on sovereignty, security, and development (Wang 2011).

\footnotetext{
${ }^{7}$ United Overseas Bank, 2017, China: Belt and Road Initiative And What It Means, accessed at: https://www.uobgroup.com/assets/pdfs/research/FN_170518A.pdf
} 
Yet if a grand strategy can be seen as a "collection of plans and policies that comprise the state's deliberate effort to harness political, military, diplomatic, and economic tools together to advance that state's national interest" (Feaver 2009) then the BRI seems to fit the bill. The BRI consists primarily of the Silk Road Economic Belt and the 21st Century Maritime Silk Road. The former, first announced by Xi during his visit to Kazakhstan in September 2013, has the stated aim to connect China, Central Asia, Russia and Europe, linking China and the India Ocean with the Persian Gulf and the Mediterranean Sea through central Asia (Nordin and Weissmann, 2018). One month later, when Xi visited Indonesia, he called for the establishment of the 21st Century Maritime Silk Road, which is designed to run through a vast sea area spanning from Europe to the Pacific (Du and Zhang 2018). The overland route aims for Central Asia and Eastern Europe to be both a transhipment hub and commodities supplier, while the maritime route links the world's most populous areas (Baker Mckenzie 2017).

The BRI has global implications. A 2016 Chinese state report indicates that BRI covers 64 countries excluding China (see Appendix 3 for the detailed list and the joining dates) along the routes. ${ }^{8}$ The report suggests that Russia, Kazakhstan, Thailand, Pakistan and Indonesia are the five most cooperative countries in advancing the BRI, particularly in the automobile, construction materials, iron and steel, railway and information communication sectors. ${ }^{9}$ It is estimated that China and the $64 \mathrm{BRI}$ countries jointly comprise $62 \%$ of the world's population, $30 \%$ of its GDP and $24 \%$ of its household consumption (Chin and $\mathrm{He}$ 2016). As the Chinese government claims that the BRI is an open platform for all parties that are willing to contribute to global connectivity, the scope of BRI can expand beyond 64 countries and some other 48 countries are, or will be, active participants in BRI (Chin and He 2016). A 2018 report suggests that the BRI coverage has expanded to 71 countries excluding China. ${ }^{10}$

China is placed squarely at the geographical and economic centre of these routes, potentially enabling it to use that position to increase its regional and international influence ( $Y u$ 2017). Infrastructure connectivity is the dominant idea behind the BRI, as Xi stressed in May 2017, "infrastructure connectivity is

\footnotetext{
${ }^{8}$ State Information Centre, 2016, Big Data Report on the Belt and Road Initiative (《“一带一路” 大数据报告 ( 2016)》), Accessed at: http://www.sic.gov.cn/News/553/7057.htm

${ }^{9}$ Belt and Road Portal, 2016, China issues first big data report on Belt and Road Initiative, Accessed at: https://eng.yidaiyilu.gov.cn/qwyw/rdxw/2248.htm

${ }^{10}$ State Information Centre, 2018, Big Data Report on Trade Cooperation Under the Belt and Road Initiative, http://www.sic.gov.cn/archiver/SIC/UpFile/Files/Default/20180509162109827517.pdf
} 
the foundation of development through cooperation."11 ${ }^{11}$ The core idea is for Beijing to provide loans and implementation capacity for pipelines, roads, ports, and other infrastructure projects. The emphasis on infrastructure and financing abroad has domestic benefits for Beijing insofar as it can alleviate problems of overcapacity in areas like cement, steel, and aluminium and ideally provide financial returns when the loans are repaid (Ferdinand 2016: 951-952; Eisenman and Stewart 2017; Economy: 2018: 190-196). This would allow China to decrease its economy's dependence on domestic infrastructure investment and help its domestic enterprises seek new markets abroad.

Furthermore, by upgrading infrastructure along BRI routes, China can reduce the costs of transporting goods for itself and other countries. ${ }^{12}$ This becomes important when one considers that some countries along the BRI routes are resource-rich, and reliable transport infrastructure can help China to secure its energy supply. In non-energy sectors, the increased connectivity and economic growth stimulated by the BRI could create a new demand for China's goods and services.

While there is significant debate about how much the BRI will actually deliver on its ambitious promises (Eisenman and Stewart 2017; Rolland 2017b; Hillman 2018), one thing is clear: Beijing is prioritizing it with vigour. At the multilateral level, Chinese-led development banks, most notably the Asia Infrastructure Investment Bank (AIIB), are supporting projects under BRI (Hurley et al. 2018). In May 2017, China hosted the first Belt and Road Forum in Beijing, in which 29 Heads of State and delegations from 130 countries and 70 international organisations attended. ${ }^{13}$

Domestically, in November 2013, the Third Plenary Session of the 18th Central Committee of the Communist Party of China (CPC), a pivotal meeting of the CPC Central Committee, called for the BRI to further open up inland and border areas. ${ }^{14}$ In May 2015, China's $13^{\text {th }}$ five-year plan emphasized the BRI. ${ }^{15}$ The CCP Leading Small Group for Advancing the Development of One Belt One Road is meant to coordinate and oversee the BRI nationally. Premier Li Keqiang

${ }^{11}$ Xinhua, 2017, Work Together to Build the Silk Road Economic Belt and the 21st Century Maritime Silk Road, accessed at: http://www.xinhuanet.com/english/2017-

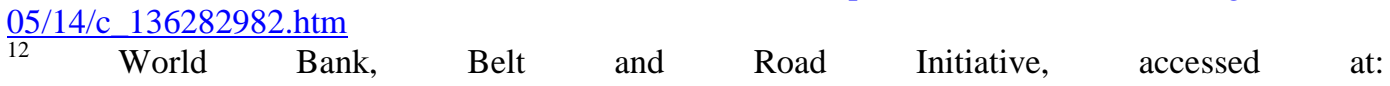
https://www.worldbank.org/en/topic/regional-integration/brief/belt-and-road-initiative

13 Xinhua, 2017, Beijing enters Belt and Road time, accessed at: http://www.xinhuanet.com/english/2017-05/13/c_136280110.htm

${ }^{14}$ Central Committee of the Communist Party of, China, 2013, Decision of the Central Committee of the Communist Party of China on Some Major Issues Concerning Comprehensively Deepening the Reform, China org, accessed at: http://www.china.org.cn/china/third_plenary_session/201401/16/content_31212602.htm

15 Sidney Leng, "How the next fi ve-year plan will change China: blueprint for nation's development explained," South China Morning Post, November 3, 2015. 
has highlighted the necessity of building and accelerating BRI in his annual government work report every year since $2014 .^{16}$ China in 2014 set up a sovereign wealth fund, the Silk Road Fund, to focus on funding projects along BRI routes. ${ }^{17}$ At the sub-national level most provinces and state-owned enterprises have incorporated the BRI into their strategic planning (Economy 2018: 193).

By promoting a vast grand strategic program of infrastructure projects, China aims strengthen its economic and political leadership in its neighbouring regions, and ultimately globally (Cai 2017). The BRI allows China to bolster its position in the US-led international order, ideally without being perceived as aggressive. ${ }^{18}$ As a rising power, China faces increasing tensions with the US. While recognising that the US will remain a superpower for decades even after the global financial crisis, China aims to secure its interests, particularly those in Asia-Pacific region, and looks forward to gaining international influence (Chan 2014; Callahan 2016). China thus advances the BRI as a strategy to deal with its competition with the US (Chan 2018). By promoting the BRI, China aims to intensify relations with traditional US allies in East Asia, which in turn can undermine US influence.

It is clear then, that China has ambitious plans with the BRI, but other countries have agency to respond to the grand strategies of powerful states. Indeed, how others perceive the BRI and engage with it is key to its long-term development. For this reason, states legitimize their grand strategies to "explain themselves in terms that others comprehend and find acceptable" in order to "shape how other nations respond" (Goddard and Krebs 2015: 13-14). Indeed, China has a robust external propaganda apparatus (Edney 2014; Brady 2015; Tsai 2017) that it has used to promote the BRI.

The results of the BRI charm offensive are still unfolding. The number of states and the scale of the proposed projects are impressive, and the project has staunch backers in some Central Asian states, but there are also signs of emerging wariness. While skepticism from Washington and Tokyo is to be expected for geopolitical and ideological reasons, more dismaying from Beijing's perspective are recent signs of discomfort in previously enthusiastic states. Pakistan's new government, for example, aims to re-visit the terms of its

\footnotetext{
${ }^{16}$ Wang likan, 2018, 2018年政府工作报告 : 五提“一带一路” (2018 Government Work Report: the fifth times to discuss Belt and Road initiative), Belt and Road Porta, accessed at: https://www.yidaiyilu.gov.cn/xwzx/gnxw/49561.htm

${ }^{17}$ Silk Road Fund, http://www.silkroadfund.com.cn/enweb/23775/23767/index.html

18 Wei Liu, 2018, The Belt and Road Initiative: A Bellwether of China's Role in Global Governance, Carnegie-Tsinghua Center for Global Policy, Accessed at: https://carnegietsinghua.org/2018/09/10/belt-and-road-initiative-bellwether-of-china-s-role-inglobal-governance-pub-77204
} 
engagement with the BRI project and the China-Pakistan Economic Corridor. ${ }^{19}$ The incoming government of Mahathir Mohamad in Malaysia cancelled over \$22 billion worth of BRI projects in August 2018 over concerns about accumulating debt. ${ }^{20}$ September 2018 elections in Maldives saw a new government take power that appears concerned about the debt it incurred as part of the BRI under the previous government (Ramachandran 2018). In Sri Lanka public unrest resulted because the government was unable to pay back Chinese loans for the Hambantota Port, leading Sri Lanka to hand over the port on a 99-year lease. ${ }^{21}$

Decisions about the BRI by recipient states do not unfold in a geopolitical vacuum. The BRI is not the only source of aid or financing available to states weighing their options. As mentioned in the introduction to this article, in addition to pre-existing sources of resources like the World Bank or Asian Development Bank, the United States has announced significant new initiatives to spend via a newly formed US International Development Finance Corporation (USIDFC). The United States, Japan, and Australia have also announced a joint initiative to invest in Asian infrastructure. ${ }^{22}$ The question remains of whether there is a global competition emerging in the realm of foreign aid in response to China's BRI. The following two sections turn to the theoretical and empirical contours of this question.

\subsection{The Politics of Strategic Aid}

Scholarship on the political economy of foreign aid has long debated if development efforts are driven by altruism or are, instead, part of broader foreign policy strategies (McKinlay and Little 1977). While evidence has emerged on both sides of the debate, it is nearly universally held that the foreign aid politics during the Cold War era was driven by strategic considerations (Griffin 1991; Meernik et al. 1998; Dunning 2004; Bearce and Tirone 2010). Development assistance was another tool in the war chest as the US and Soviet Union battled for supremacy in economic, cultural and security spheres. The end of this

\footnotetext{
${ }^{19}$ Jamil Anderlini, Henny Sender, and Farhan Bokhari (2018) Pakistan Rethinks its Role in Xi's Belt and Road Plan. Financial Times 9 September 2018. Available at: https://www.ft.com/content/d4a3e7f8-b282-11e8-99ca-68cf89602132 (accessed 30 October 2018). 20 Alexandra Ma, "Malaysia has Axed \$22 Billion of Chinese-backed Projects" UK Business Insider 21 August 2018. Available at: http://uk.businessinsider.com/malaysia-axes-22-billion-ofbelt-and-road-projects-blow-to-china-2018-8 (accessed 30 October 2018).

${ }^{21}$ Maria Abi-Habib (2018) How China Got Sri Lanka to Cough Up a Port. New York Times 25 June 2018. Available at: https://www.nytimes.com/2018/06/25/world/asia/china-sri-lankaport.html (accessed 30 October 2018).

${ }^{22}$ The Japan Times, "Japan, US and Australia Plan Infrastructure Push to Counter China in IndoPacific." $31 \quad$ July $2018 . \quad$ Available at: https://www.japantimes.co.jp/news/2018/07/31/national/politics-diplomacy/japan-u-s-australiaplan-infrastructure-push-counter-china-indo-pacific/\#.W9hTMieYTOQ (accessed 30 October 2018).
} 
ideological confrontation marked a decided turn in the rhetoric, if not behavior, of the Western development partners. While more recent foreign aid efforts are not entirely devoid of self-interested motivation, the lack of a great power game turned foreign aid into a tool for targeted development aims rather than a simple payoff to increase one's geostrategic coalition (Bermeo 2017).

The politics of strategic foreign aid requires rationalist calculations by both the competing donors but also by the recipient country. First, recipient countries' "natural" alignment will substantively influence their foreign aid positioning. Countries will align with donors with whom they share strong ideological, cultural or security ties (Alesina and Dollar 2000). Attempting to "turn" these countries through the use of foreign aid is likely to be prohibitively costly. As such, strategic foreign aid competition is likely to focus on those countries who are sufficiently ambiguous in their ties (Lundborg 1998). These "in play" countries attempt to maximize their payoff by playing competing donors off one another. In this game, there is a distinct first mover advantage to the donor which initially courts the recipient. Initial alignment both sets a reservation price for the competing donor, but also sends a signal that the recipient may be closer to that donor's "type" which can cause the competitor to change expectations about the cost of "turning" the country.

The BRI provides an interesting context for examining this strategic logic. While dozens of countries are on the proposed BRI economic corridors, there is substantial variation in the extent to which different countries have received financing under the initiative. This allows identification of states that are either (a) naturally aligned and/or had China as first mover and those that (b) are of interest to China, but where China has not yet expended significant resources. As such, based on the reasoning above, the most likely strategic response by the US to the BRI would be directed towards the latter of these types of states.

The US has two avenues to respond to Chinese BRI flows. First, the US can engage directly via bilateral programs, such as the IDFC. However, Dreher et al. (2018b) have recently argued that the US has incentives to use international organizations to conduct its "dirty work" when using aid strategically. The logic of this behavior is that using these organizations will reduce audience costs in instances where the foreign aid intervention might be viewed unfavorably. As many of the (potential) BRI countries are those to whom US domestic audiences might not be favorable, international organizations such as multilateral development banks become a useful instrument for countering the BRI. And indeed, the US has been shown as the "power behind the throne" of a number of major multilateral development banks (MDBs), and, accordingly, Western MDBs are often seen as the agent of a powerful US principle (Andersen et al. 2006; 
Andersen et al. 2006b; Kilby 2006; Dreher and Jensen 2007; Dreher et al. 2009a; Dreher et al 2009b). ${ }^{23}$ As such, we hypothesize that:

Hypothesis 1: The US will be more likely to support MDB programs in countries which are in the $B R I$.

Hypothesis 2: As the amount of Chinese financing increased, the US will be less likely to support MDB programs to countries in the BRI.

\section{Data and Methods}

\subsection{Data}

To evaluate our claims, we use panel data on 157 countries (see Appendix 1 for list of countries) covering over 6975 project/loan packages in 16 MDBs (see Appendix 2 for list of MDBs) for the period 2013-2018 (February). Since some of the data (for control variables) are not available for all countries and for all years, our dataset is unbalanced. We estimate the probability of US support for loan package of country $\boldsymbol{c}$ in Bank $\boldsymbol{b}$ in year $\boldsymbol{t}$ as:

$$
P\left(\text { support }_{c b t}=1\right)=\varphi_{c}+\beta B R I_{c t}+\beta Z_{c t}+\lambda_{t}+\omega_{c b t}
$$

where support $_{c b t}$ is a discrete variable taking the value 1 if US supports the loan package put forth by country $\boldsymbol{c}$ for approval in MDB $\boldsymbol{b}$ in year $\boldsymbol{t}$ and 0 otherwise. We measure US support by examining the voting record on the Executive Board of each MDB made available by the US Treasury Department on its website since 2004. An Executive Board member country can exercise the choice of 'yes' vote which denotes approval for that project under consideration, while a 'no' vote means disapproval. The choice of 'abstaining' from voting we believe is also a sign of disapproval but to a lesser degree than an outright 'no' vote. Therefore, our dependent variable is US support for a loan package, i.e., 'yes' vote $=1$ and 0 otherwise.

Our main explanatory variable is a novel indicator, $\boldsymbol{B} \boldsymbol{R} \boldsymbol{I}_{c t}$, which is a dummy coded 1 if country $\boldsymbol{c}$ is a member of the BRI at year $\boldsymbol{t}$ and 0 otherwise. We use a three-step approach and relied on several sources to construct this BRI membership measure. First, we checked if a Memoranda of Understanding (MoU) on Belt and Road Initiative (BRI), Silk Road Economic Belt (SRB) or 21st Century Maritime Silk Road (MSR) has been signed between a country and China.

\footnotetext{
${ }^{23}$ With a notable counter being Strand and Zappile (2015) who suggest that the level of US influence in MDBs may be overstated.
} 
This information is made available by China's Foreign Affairs Ministry, ${ }^{24}$ under the BRI section.

In the second step, we rely on the joint statements issued by the recipient country and China emanating from the meetings of leaders of both countries (heads of the state or government) or senior leaders, and the official declarations and communiques of China's Foreign Affairs Ministry, ${ }^{25}$ in which a country either expresses a strong support and further cooperation on Chinese BRI, SBR or MSR programs or is a signatory to allowing contracting and sub-contracting of various projects under BRI. We cross-checked these activities under each country's profile in the Ministry of Foreign Affairs of China ${ }^{26}$, to see if a country has joined BRI but was not mentioned in official communiques or joint statements.

In the final step, we reviewed all the articles made publicly available at the Ministry of Foreign Affairs of China, The State Council, the Ministry of Commerce of China, and the Department of National Development and Reform Commission (DNDRC). Appendix 3 provides further details and a list of 65 countries with BRI membership and Exhibit 1 displays information on various joint statements issues by Ministry of Foreign Affairs of China covering the BRI topics.

The vector $\boldsymbol{Z}_{c t}$ includes potential determinants of US support for loan packages gleaned from the existing literature on donor influence in MDBs (Braaten 2014, Dreher et al. 2009a, Kilby 2006, Andersen et al. 2006a, Lai 2003, Alesina and Dollar 1998). We use one year lagged values of all control variables to allow for the lag effect on US voting pattern. We also avoid the "garbage can" approach and limit our control variables (Achen 2005, Schrodt 2014). First, we include per capita GDP (log) measured in 2010 US\$ constant prices. Income per capita is a 'catch all' variable for factors such as level of economic development therefore serving as a proxy for need of recipient countries (Morrison 2011, Fleck and Kilby 2006). We also control for country size using population (log) as large countries natural tend to have a higher need for MDB aid projects (Andersen et al. 2006, Fleck and Kilby 2006). Both per capita income and population variables are sourced from the World Development Indicators (WDI) 2018.

Next, we control for regime type using the Polity IV index of democracy which measures regime type along a scale of -10 (strict autocracy) to 10 (full

\footnotetext{
${ }^{24}$ 中国外交部---新闻/重要新闻/一带一路专栏下的重要新闻 An English version of the same is available http://www.fmprc.gov.cn/mfa_chn//ziliao_611306/zt_611380/dnzt 611382/ydyl_667839/zyxw_6 67918/

${ }^{25}$ 中国外交部---声明公报, An English version of the same is available at: http://www.fmprc.gov.cn/web/ziliao 674904/1179 674909/

${ }^{26}$ 中国外交部一国家地区一该国家的重要文件或者重要新闻,
} 
democracy) (Gurr and Jaggers 1995). It has been argued that promoting democracy and democratic institutions have long been a US foreign policy objective (Lawson and Epstein 2017, Peterson and Scott 2017, Demirel-Pegg and Moskowitz 2009). With specific reference to MDBs, Braaten (2014) finds that political rights to be an important determinant of US voting pattern.

We also control for US exports to recipient countries measured in US\$ million (log) which is sourced from the US Bureau of Economic Affairs (BEA) foreign trade statistics (2018). This variable captures economic importance of the recipient to the US. Therefore, if strength of commercial relationship matters, then we expect a positive relationship between US exports and support for loan packages in MDBs for those countries. Indeed, Braaten (2014) finds that countries which import more from the US are more likely to be rewarded with approval of their loan packages. Likewise, we also expect US to reward its allies in the MDBs (Andersen et al. 2006a). We use the UNGA voting alignment index developed by Voeten $(2000,2004)$ and Strezhnev and Voeten (2012) covering the key votes of interest for the US. ${ }^{27}$ Next, we include a measure of US aid (log) measured in US\$ millions sourced from the WDI (2018) to account for its influence in the MDBs (Kilby 2006). One assumption is that US would use its influence in MDBs to approve projects for countries which receive large US aid (Morrison 2011). On the contrary, one could expect a negative relationship as US ends up paying only a fraction of the loan cost involved if economic support is channeled through MDBs, or if the US is using the MDB for its "dirty work" (Dreher and Strum 2012; Dreher et al. 2018b).

Finally, we include a dummy measure of conflicts with at least 25 battlerelated deaths during a year sourced from the Uppsala Conflict Data Program (UCDP) Armed Conflict Dataset (Gleditsch et al. 2002). We expect ongoing conflict to impede the US from approving loan packages. The descriptive statistics on all the variables are reported in Appendix 4 and the details on definitions and data sources are provided in Appendix 5.

To evaluate hypothesis 1 , that the US will support MDBs programs for countries in the BRI, we use a logit estimator with heteroskedasticity consistent robust standard errors. One drawback of the logit estimations is that we cannot include country-fixed effects for two reasons. First, the use of two-way fixed effects will be co-linear with time-invariant regressors (Beck 2001). For BRI member countries, for example, the data do not vary over the time period once they enter into the BRI program. Likewise, polity IV index and civil conflict dummy measures vary slowly over time. Secondly, including two-way fixed effects in non-linear estimations, like the logit estimator, may be problematic

${ }^{27}$ We update the index from 2016 until 2017. 
due to the well-known incidental parameter problem (Lancaster 2000, Wooldridge 2002). The standard approach is a conditional logit method developed by Chamberlain (1980) which allows controlling for fixed effects by maximising the conditional likelihood function as:

$$
L=\Pi_{i=1}^{N} \quad P\left(y_{i 1}, \ldots y_{i T} \mid \sum_{i=1}^{T} y_{i t}\right)
$$

Wherein, $\boldsymbol{T}$ is the last observation for country $\boldsymbol{i}$. However, conditional logit fixed effects estimator is not free from limitations. The first problem is that it estimates the $1 \mathrm{~s}$ and 0 s for each country conditioned by total number of $1 \mathrm{~s}$ for each country. Thus, if country $i$ never reports an onset event (no 1s) or only reports onset events (only 1s) then the conditional probability of observing the data for country $i$ is 1 , which means that country $i$ is automatically dropped from the analysis.

Second, unlike a simple univariate logit estimator, the coefficients from conditional logit fixed effects are hard to interpret because it does not allow for computation of marginal effects making it difficult to derive the substantive effects. To circumvent these problems, we follow two approaches. First, we estimate logit models controlling for geographic regional dummies along with year fixed effects. Second, along with controlling geographic regional dummies and year fixed effects, we also include MDB specific dummies thereby depicting a fixed effects model. ${ }^{28}$

\subsection{Endogeneity and Instrumental Variable Approach}

Our BRI membership measure could be also affected by endogeneity problems if BRI membership, for example, is an outcome rather than cause of US voting pattern in the MDBs. This issue is not trivial because those who argue that $\mathrm{BRI}$ provokes US response also make causal claims that BRI project is an outcome to challenge the economic and international world order dominated by the US (Yu 2017, Wang 2016). Moreover, endogeneity could be an issue if the membership for a country in the BRI resulted in US approving loan package for that country in an MDB to placate Chinese influence (Jiangtao 2018). Furthermore, the BRI could be caused by other factors which could also explain US voting pattern at the MDBs, such as China using BRI to stimulate trade surplus (Boffa 2018; Bastos 2018; Chen et al. 2018), promote outward FDI (Du and Zhang 2018), build regional influence thereby undercutting US influence (Meltzer 2017), increase international use of Renminbi (Shen and Chan 2018), fostering strategic divisions among US allies (Shen 2016), and/or creating new economic world

\footnotetext{
${ }^{28}$ As further robustness, we also use probit random effects estimator developed by Chamberlain (1992).
} 
order as an alternative to the US led pro-market capitalist model (Shen and Chan 2018).

To address this problem, we employ an instrumental variable and estimate an instrumental variable probit. ${ }^{29}$ Following Dreher et al. $(2017,2018)$ we use, the probability of a recipient country receiving Chinese aid weighted by steel production (log) in China, $i v=\left[\frac{1}{15} \sum_{y=1}^{15} p_{i t} \times \ln (\text { steel })_{t}\right]$ which is lagged by two-years. While the steel production data comes from the World Steel Association's statistical yearbook (2017), the probability of receiving Chinese aid is the percentage share of years during the period 2000-2014 (for which Chinese aid data is available) a recipient has received Chinese aid. Interacting these two variables tell us whether countries with a high probability to receive Chinese aid is driven by excess steel production in China. We believe that China can use the BRI to sustain its economic growth which has considerably slowed down in the recent years. Thus, fostering new economic opportunities through BRI could enable China to support of its economic growth (Yu 2017). Zhai (2018) and Huang (2016) argue that infrastructure development is a crucial element of the BRI in which the thrust is on infrastructure connectivity such as building new trains and locomotives, high-speed railroads, ports, highways, oil and gas pipelines, telecom and electricity infrastructure. All these projects will result in increase in demand for products like excess steel which will be utilized in building these projects across countries. To this effect, Dreher et al. $(2017$, p. 4) argues that, "the Chinese government considers steel to be a strategically important commodity and therefore maintains excess production capacity. This policy choice by the Chinese government results in a surplus of steel, some of which China uses for aid projects around the world. In years when production volumes are high, China's supply of aid is also higher." Thus, the identifying assumption is the same as in Dreher et al. (2017) that US voting pattern in MDBs will not be affected by changes in steel production in China, other than its impact on BRI membership. We employ the ivprobit estimator including all the control variables discussed above along with year fixed effects and geographic regional dummies. We compute a Wald test for assessing the exogeneity of our instrumented variable.

The validity of the instrument depends on two conditions. The first issue is instrument relevance, which is that the instrument must be correlated with the explanatory variable in question - otherwise it has no power. In the case of linear estimations, Bound, Jaeger and Baker (1995) suggest examining the joint F-

\footnotetext{
${ }^{29}$ We also utilize a two-stage least squares instrumental variable (2SLS-IV hereafter).
} 
statistic on the excluded instrument in the first-stage regression. The selected instrument would be relevant when the first stage regression model's joint Fstatistics is above 10 (Bound, Jaeger and Baker 1995). Since we estimate a nonlinear model, we employ the Wald test of exogeneity to test the null hypothesis of no endogeneity. If the p-value from Chi-squared in the Wald test is indistinguishable from zero then null hypothesis of no endogeneity is rejected, supporting the validity of the instrumental variable approach (Wooldridge 2002: 472-477). We estimate the first step regression using logit maximum-likelihood estimator to assess the relevance of the selected instrument.

Second, the selected instrument should not differ systematically with the error term in the second stage of the equation, i.e. $\left[\omega_{i t} \mid I V_{i t}\right]=0$, meaning the selected instrument should not have any direct effect on the outcome variable of interest - US voting in MDBs, but only indirectly via the instrumented variable. To the best of our knowledge we are not aware of any theoretical proposition or empirical test linking the changes in steel production in China and US voting pattern in the MDBs.

\subsection{Interaction effects}

To evaluate hypothesis two, if the effect of BRI membership on US voting in MDBs is conditional upon the level of Chinese development aid, we estimate:

$$
\begin{aligned}
P\left(\text { support }_{c b t}\right. & =1) \\
& =\varphi_{c}+\beta(B R I \times \text { China })_{c t}+\beta B R I_{c t}+\beta \text { China }_{c t}+\beta Z_{c t}+\lambda_{t} \\
& +\omega_{c b t}(2)
\end{aligned}
$$

where $(B R I \times \text { China })_{c t}$ is an interaction term between BRI membership and a conditioning variable, China $_{c t}$ which is Chinese development aid as a share of total DAC aid in country $\boldsymbol{c}$ during year $\boldsymbol{t}$. While DAC aid data is sourced from the WDI (2018), we source Chinese aid data from the newly released global dataset on Chinese development activities - the AidData's Global Chinese Official Finance Dataset, version 1.0 (AidData 2017) developed by Dreher et al. (2017). ${ }^{30}$ This data captures official Chinese state finance which includes both foreign aid- which is akin to the OECD's Official Development Assistance (ODA), and other forms of state financing (concession and non-concessional)- which is similar to the OECD's Other Official Flows (OOF) with development or commercial intent. ${ }^{31}$ The dataset covers Chinese aid activities in 138 countries during the 2000-2014 period. This dataset has been used by scholars to examine

\footnotetext{
${ }^{30}$ See: http://aiddata.org/data/chinese-global-official-finance-dataset

${ }^{31}$ For further details on methodology and data, see: Bluhm et al. (2018) and AidData Research and Evaluation Unit (2017).
} 
the causes and consequences of Chinese aid in Africa (e.g., Dreher et al. 2018, 2017, Isaksson and Kotsadam 2018, Brazys et al. 2017, Hernandez 2017, Strange et al. 2017). As mentioned earlier, we use one-year lagged values of all our variables. ${ }^{32}$ Once again, we employ logit estimator with year fixed effects estimator and generate marginal plots to assess the interaction effects.

\section{Empirical Results}

Table 1 reports the impact of the BRI on US voting pattern in the MDBs. Column 2 presents the results of the models with controls. We then control for geographic regional dummies and fixed effects for MDBs in a step-wise manner in columns 2-4. Table 2 presents the same models but using the IV probit estimator to address endogeneity concerns. Finally, Table 3 presents the results of the interaction effects between BRI and dominance of Chinese aid.

As seen in Table 1, membership in the BRI is associated with an increased probability of a yes vote by the US at the MDBs, with the results statistically significant at the $1 \%$ level in all models, including those with controls, MDB fixed effects and region dummies. Notice that the substantive effects are fairly large. ${ }^{33}$ Computing odds ratios suggests that BRI membership increases the probability of a yes vote by the US in the MDBs by up to $117 \%$ (column 2 ) compared with nonmembers of BRI.

\footnotetext{
${ }^{32}$ However, it is noteworthy that the Chinese aid data is made available by AidData until 2014 while our study period extends until February 2018. Therefore, we use 2014 values of Chinese aid for the year 2016 and 2017.

${ }^{33}$ The Table 1 reports coefficients instead of marginal effects usually reported for a logit estimator.

$$
\frac{\vartheta P\left(y_{i}=1 \mid x_{i}\right)}{\vartheta x_{i}}=\frac{\vartheta E(y i \mid x i)}{\vartheta x_{i}}=\varphi\left(x_{i}^{\prime} \beta\right) \beta
$$
}


Table 1: Influence of BRI initiative on US voting patterns in MDBs

\begin{tabular}{|c|c|c|c|c|}
\hline & $\begin{array}{c}\text { (1) } \\
\text { Yes vote }\end{array}$ & $\begin{array}{c}\text { (2) } \\
\text { Yes vote }\end{array}$ & $\begin{array}{c}\text { (3) } \\
\text { Yes vote }\end{array}$ & $\begin{array}{c}(4) \\
\text { Yes vote }\end{array}$ \\
\hline Belt Road Initiative membership & $\begin{array}{c}0.777^{* * *} \\
(0.103)\end{array}$ & $\begin{array}{c}0.583^{* * *} \\
(0.127)\end{array}$ & $\begin{array}{c}0.570^{* * *} \\
(0.107)\end{array}$ & $\begin{array}{c}0.530^{* * *} \\
(0.129)\end{array}$ \\
\hline Per capita GDP $(\log )$ & $\begin{array}{c}-0.693^{* * *} \\
(0.0707)\end{array}$ & $\begin{array}{c}-0.833^{* * *} \\
(0.0852)\end{array}$ & $\begin{array}{c}-0.776^{* * *} \\
(0.0761)\end{array}$ & $\begin{array}{c}-0.844^{* * *} \\
(0.0862)\end{array}$ \\
\hline Population (log) & $\begin{array}{c}-0.431^{* * *} \\
(0.0489)\end{array}$ & $\begin{array}{c}-0.290^{* * *} \\
(0.0652)\end{array}$ & $\begin{array}{c}-0.377^{* * *} \\
(0.0548)\end{array}$ & $\begin{array}{c}-0.282^{* * *} \\
(0.0661)\end{array}$ \\
\hline Democracy Polity index & $\begin{array}{l}0.0580^{* * *} \\
(0.00703)\end{array}$ & $\begin{array}{l}0.0748^{* * *} \\
(0.00855)\end{array}$ & $\begin{array}{l}0.0608^{* * *} \\
(0.00719)\end{array}$ & $\begin{array}{l}0.0751^{* * *} \\
(0.00859)\end{array}$ \\
\hline US Exports (log) & $\begin{array}{l}0.259^{* * *} \\
(0.0376)\end{array}$ & $\begin{array}{l}0.183^{* * *} \\
(0.0551)\end{array}$ & $\begin{array}{l}0.230^{* * *} \\
(0.0440)\end{array}$ & $\begin{array}{l}0.182^{* * *} \\
(0.0558)\end{array}$ \\
\hline UNGA Voting alignment index & $\begin{array}{c}1.023^{* * *} \\
(0.309)\end{array}$ & $\begin{array}{c}0.556 \\
(0.344)\end{array}$ & $\begin{array}{c}0.737^{* *} \\
(0.325)\end{array}$ & $\begin{array}{c}0.537 \\
(0.350)\end{array}$ \\
\hline US Aid (log) & $\begin{array}{c}-0.0360^{\star * *} \\
(0.00762)\end{array}$ & $\begin{array}{c}-0.0290^{* * *} \\
(0.00812)\end{array}$ & $\begin{array}{c}-0.0346^{* * *} \\
(0.00772)\end{array}$ & $\begin{array}{c}-0.0312^{* * *} \\
(0.00835)\end{array}$ \\
\hline Civil conflict & $\begin{array}{c}0.270^{* * *} \\
(0.103)\end{array}$ & $\begin{array}{c}0.171 \\
(0.113)\end{array}$ & $\begin{array}{l}0.261^{\text {** }} \\
(0.106)\end{array}$ & $\begin{array}{c}0.186 \\
(0.114)\end{array}$ \\
\hline East Asia dummy & & $\begin{array}{l}0.294^{* *} \\
(0.150)\end{array}$ & & $\begin{array}{c}0.130 \\
(0.171)\end{array}$ \\
\hline South Asia dummy & & $\begin{array}{l}-0.0592 \\
(0.177)\end{array}$ & & $\begin{array}{l}-0.213 \\
(0.193)\end{array}$ \\
\hline Europe \& Central Asia dummy & & $\begin{array}{c}1.000^{* * *} \\
(0.184)\end{array}$ & & $\begin{array}{c}0.577^{* * *} \\
(0.199)\end{array}$ \\
\hline Latin America \& Caribbean dummy & & $\begin{array}{c}0.745^{* * *} \\
(0.187)\end{array}$ & & $\begin{array}{c}0.332 \\
(0.222)\end{array}$ \\
\hline MENA dummy & & $\begin{array}{c}0.982^{* * *} \\
(0.197)\end{array}$ & & $\begin{array}{c}0.760^{* * *} \\
(0.201)\end{array}$ \\
\hline Constant & $\begin{array}{c}13.08^{* * *} \\
(1.092)\end{array}$ & $\begin{array}{c}11.77^{* * *} \\
(1.346)\end{array}$ & $\begin{array}{c}12.92^{* * *} \\
(1.205)\end{array}$ & $\begin{array}{c}11.95^{* * *} \\
(1.370)\end{array}$ \\
\hline Estimator & Logit & Logit & Logit & Logit \\
\hline Year Fixed Effects & Yes & Yes & Yes & Yes \\
\hline MDBs Fixed Effects & No & No & Yes & Yes \\
\hline Number of MDBs & 16 & 16 & 10 & 10 \\
\hline Number of countries & 119 & 119 & 119 & 119 \\
\hline Total Observations & 6,074 & 6,074 & 6,067 & 6,067 \\
\hline
\end{tabular}
Note:

(1) Standard errors in parenthesis.

(2) Statistical significance: ${ }^{* *} p<0.01,{ }^{* *} p<0.05,{ }^{*} p<0.1$ 
The results of control variables are in line with theoretical expectations and are all statistically significant at conventional levels across most models. For instance, we find a strong positive effect of Polity IV regime type index on the probability of US support which is significantly different from zero at the $1 \%$ level. ${ }^{34}$ Comparing the substantive effects, increasing Polity IV regime type index by a standard deviation increases the chance of US support in the MDBs by only $38 \%$, which suggests that the relative effect of BRI membership is substantively important. Interestingly, the only variable which has a substantially higher impact on US voting in the MDBs relative to the BRI is the UNGA voting alignment index. For instance, holding all other variables constant at their mean, a point increase in UNGA voting alignment index in favour of US is associated with $178 \%$ increase in chance of US support in the MDBs, which is roughly $52 \%$ higher than the effect of BRI membership alone. These results are in line with the existing literature on using aid to influence votes in the UNGA (Dreher et al. 2008, Dreher and Strum 2012, Kilby 2013, Woo and Chung 2018).

Finally, to further examine the predictive performance of our models reported in Table 1, we examine the ROC curves, which plot the true positive rate (or the sensitivity of the model) on the $x$-axis versus the true negative rate (or the specificity) on the $y$-axis. ${ }^{35}$ Figure 1 presents the ROC curves for the model from column 1 in Table 1, alongside a ROC curve from a regression on BRI membership alone. As seen from Figure 1, the models perform very well given the location of its line relative to the 45 degree line, which is the point at which randomly guessing the outcome lies. The Area Under Curve (AUC hereafter) ranges from 0 to 1 , with 0.5 corresponding with random performance. The shape of the curve exhibits the inverse relationship between sensitivity and specificity at different cut points. As seen there, the AUC displayed is at 0.66 and 0.65 , respectively, which is a considerable improvement over guessing. Overall, the results from Table 1 taken together indeed suggest that the China led BRI is inducing a competitive foreign aid response from the US as it is more likely to approve loan packages at the various MDBs.

\footnotetext{
${ }^{34}$ Our result on democracy is robust to alternative measure of democracy (Cheibub, Gandhi and Vreeland 2010) and when replacing the polity IV index with two dichotomous measure, namely, democracy ( 1 if the polity index is above +6 and 0 otherwise) and autocracy ( 1 if the polity index is below -5 and 0 otherwise).

${ }^{35}$ For detailed discussion on the ROC curve, see Fawcett (2006).
} 
Figure 1: In Sample ROC curve (Estimates from Table 1)

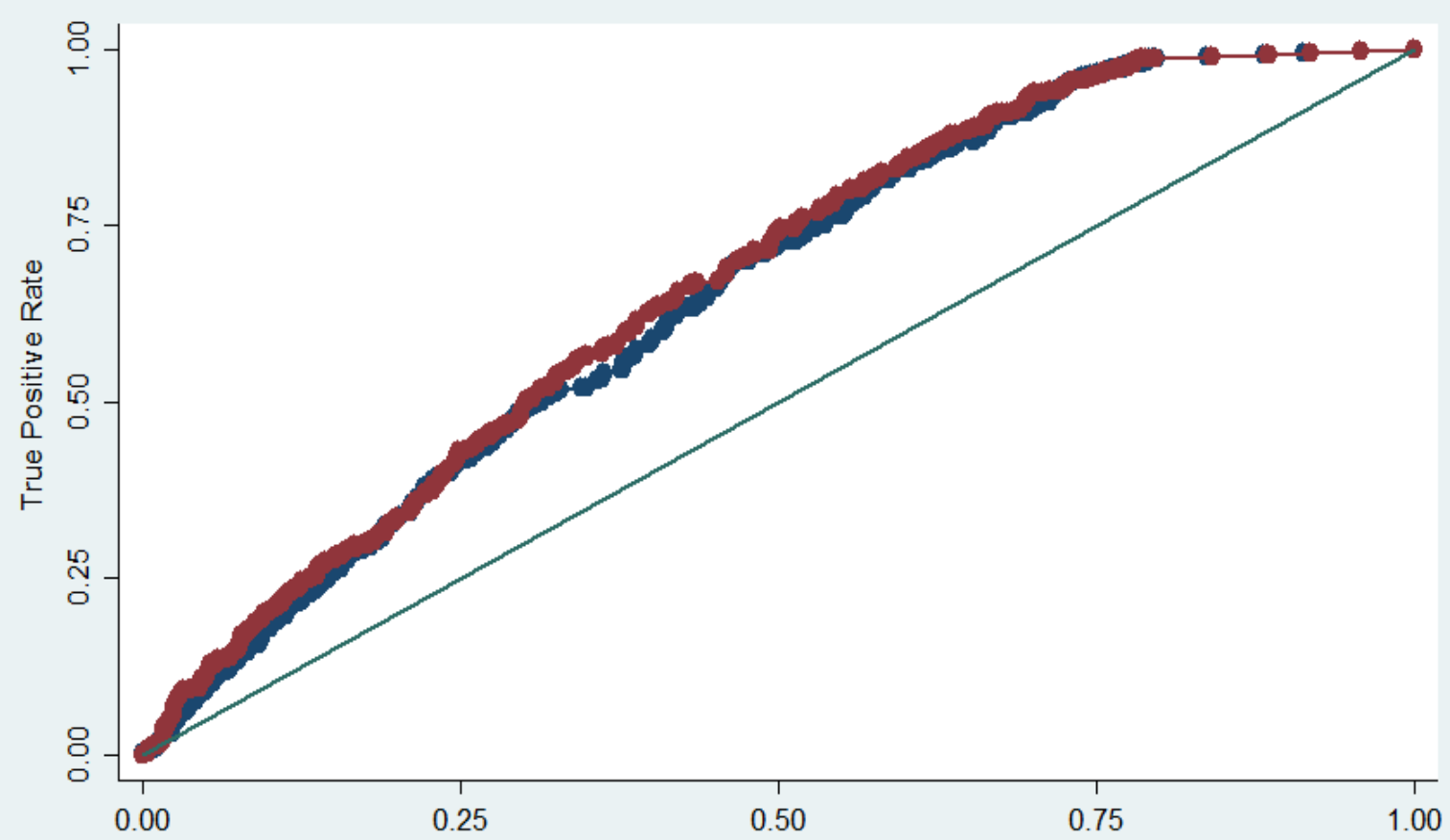

False Positive Rate

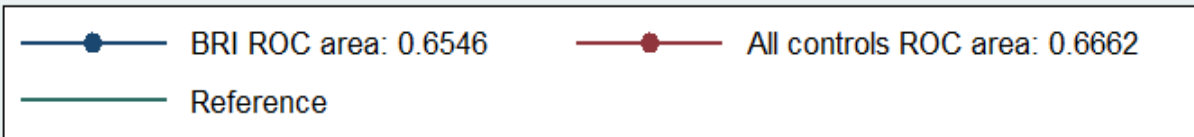

In Table 2 we present the results with instrumental variable estimations of our variable of interest. Once again, the impact of BRI membership on the probability of US "yes" votes in MDBs is positive and statistically different from zero at the 1 percent level in all models. In all four columns the $p$-value from the Wald test of exogeneity is significantly different from zero at the conventional levels of statistical significance. This suggests that the Wald test rejects the null hypothesis on no endogeneity, allowing us to use instrumental variables (Wooldridge 2002: 472-477). ${ }^{36}$

\footnotetext{
${ }^{36}$ Although it is noteworthy that the results of Wald test are weak as the chi-square is less than 10 which is the thumb rule.
} 
Table 2: Influence of BRI initiative on US voting patterns in MDBs: IV estimations

\begin{tabular}{|c|c|c|c|c|}
\hline & $\begin{array}{c}(1) \\
\text { Yes vote }\end{array}$ & $\begin{array}{c}\text { (2) } \\
\text { Yes vote }\end{array}$ & $\begin{array}{c}\text { (3) } \\
\text { Yes vote }\end{array}$ & $\begin{array}{c}(4) \\
\text { Yes vote }\end{array}$ \\
\hline Belt Road Initiative membership & $\begin{array}{c}2.168^{* * *} \\
(0.416)\end{array}$ & $\begin{array}{c}3.422^{* * *} \\
(0.290)\end{array}$ & $\begin{array}{c}1.960 * * * \\
(0.569)\end{array}$ & $\begin{array}{c}3.404^{* * *} \\
(0.294)\end{array}$ \\
\hline Per capita GDP $(\log )$ & $\begin{array}{c}-0.593^{* * *} \\
(0.0479)\end{array}$ & $\begin{array}{l}-0.225^{* *} \\
(0.0925)\end{array}$ & $\begin{array}{c}-0.499^{* * *} \\
(0.0435)\end{array}$ & $\begin{array}{c}-0.229^{* * *} \\
(0.0872)\end{array}$ \\
\hline Population (log) & $\begin{array}{c}-0.358^{* * *} \\
(0.0438)\end{array}$ & $\begin{array}{l}-0.0399 \\
(0.0252)\end{array}$ & $\begin{array}{c}-0.260^{* * *} \\
(0.0468)\end{array}$ & $\begin{array}{l}-0.0392 \\
(0.0238)\end{array}$ \\
\hline Democracy Polity index & $\begin{array}{l}0.0322^{* * *} \\
(0.00528)\end{array}$ & $\begin{array}{l}0.0379^{* * *} \\
(0.00496)\end{array}$ & $\begin{array}{l}0.0237^{* * *} \\
(0.00470)\end{array}$ & $\begin{array}{l}0.0373^{* * *} \\
(0.00486)\end{array}$ \\
\hline US Exports (log) & $\begin{array}{l}0.286^{* * *} \\
(0.0271)\end{array}$ & $\begin{array}{c}0.0449 \\
(0.0295)\end{array}$ & $\begin{array}{l}0.212^{* * *} \\
(0.0297)\end{array}$ & $\begin{array}{l}0.0468^{*} \\
(0.0271)\end{array}$ \\
\hline UNGA Voting alignment index & $\begin{array}{c}0.562^{* * *} \\
(0.137)\end{array}$ & $\begin{array}{c}0.140 \\
(0.120)\end{array}$ & $\begin{array}{c}0.528^{* * *} \\
(0.165)\end{array}$ & $\begin{array}{c}0.174 \\
(0.119)\end{array}$ \\
\hline US Aid (log) & $\begin{array}{c}-0.0333^{* * *} \\
(0.00439)\end{array}$ & $\begin{array}{c}-0.0218^{* * *} \\
(0.00264)\end{array}$ & $\begin{array}{c}-0.0269 * * * \\
(0.00493)\end{array}$ & $\begin{array}{c}-0.0220^{* * *} \\
(0.00262)\end{array}$ \\
\hline Civil conflict & $\begin{array}{l}-0.0559 \\
(0.0488)\end{array}$ & $\begin{array}{l}-0.0181 \\
(0.0436)\end{array}$ & $\begin{array}{l}-0.0315 \\
(0.0527)\end{array}$ & $\begin{array}{r}-0.00991 \\
(0.0440)\end{array}$ \\
\hline East Asia dummy & & $\begin{array}{c}-1.424^{* * *} \\
(0.305)\end{array}$ & & $\begin{array}{c}-1.349^{* * *} \\
(0.278)\end{array}$ \\
\hline South Asia dummy & & $\begin{array}{c}-2.473^{* * *} \\
(0.245)\end{array}$ & & $\begin{array}{c}-2.409^{\star * *} \\
(0.228)\end{array}$ \\
\hline Europe \& Central Asia dummy & & $\begin{array}{c}-1.817^{* * *} \\
(0.336)\end{array}$ & & $\begin{array}{c}-1.697^{* * *} \\
(0.270)\end{array}$ \\
\hline Latin America \& Caribbean dummy & & $\begin{array}{l}-0.0498 \\
(0.125)\end{array}$ & & $\begin{array}{l}-0.0519 \\
(0.0807)\end{array}$ \\
\hline MENA dummy & & $\begin{array}{c}-0.596^{* * *} \\
(0.205)\end{array}$ & & $\begin{array}{c}-0.528^{* * *} \\
(0.169)\end{array}$ \\
\hline Constant & $\begin{array}{c}9.859^{* * *} \\
(0.758) \\
\end{array}$ & $\begin{array}{c}3.411^{* * *} \\
(1.024) \\
\end{array}$ & $\begin{array}{c}7.412^{* * *} \\
(0.674) \\
\end{array}$ & $\begin{array}{c}3.285^{* * *} \\
(0.947) \\
\end{array}$ \\
\hline Estimator & Logit & Logit & Logit & Logit \\
\hline Year Fixed Effects & Yes & Yes & Yes & Yes \\
\hline Wald test of exogeneity & $6.19^{* *}$ & $4.37^{* *}$ & $5.00^{* *}$ & $5.33^{* *}$ \\
\hline MDBs Fixed Effects & No & No & Yes & Yes \\
\hline Number of MDBs & 16 & 10 & 10 & 10 \\
\hline Number of countries & 102 & 102 & 102 & 102 \\
\hline Total Observations & 5,319 & 5,319 & 5,312 & 5,312 \\
\hline
\end{tabular}

Note:

(1) Standard errors in parenthesis.

(2) Statistical significance: ${ }^{* *} p<0.01, * * p<0.05,{ }^{*} p<0.1$ 
Substantively, the IV estimation results on BRI membership are even larger than those reported in our baseline estimates in Table 1. One plausible reason could be the attenuation bias from measurement error in the BRI membership dummy variable which does not fully capture the intensity of initiative due to lack of further information and details about the number, scope, nature and size of the BRI projects and the amount involved. This may create a measurement error problem which drowns the reverse causality and omitted variable bias. Addressing the measurement error in the BRI membership variable would tend to make the logit estimates greater than the IV probit estimates. To further examine whether the difference in odds ratio between logit and IV probit estimates is due to measurement error in the BRI membership variable, we use total Chinese aid (log) measured in million US\$ sourced from AidData (2017) database as an instrument for BRI membership variable. The odds ratio from IV probit regression estimates suggests a $638 \%$ increase in chance of US supporting the loan proposals in MDBs. These large effects suggest that the difference between logit and IV probit estimates is indeed due to the measurement error of our BRI variable which does not capture the intensity of BRI projects at work. Of course, needless to say that this exercise is not the optimal solution to solve the endogeneity concerns as Chinese aid does not qualify the instrument exclusion restriction criteria.

In Table 3, we introduce interaction terms between BRI membership and Chinese aid dominance in recipient countries using the ratio of Chinese aid to total aid from countries belonging to the OECD's Development Assistance Committee (DAC) to evaluate hypothesis 2 . In column 1 we report the results from an interaction term without including any control variables. While column 2 report the interaction results controlling for other control variables, in column 3 geographic regional dummies are also included. As seen in column 1, the interaction term is negative and statistically significant at the $1 \%$ level. Interestingly, when the BRI membership is 0 , the Chinese aid to DAC aid measure has a positive significant effect on US yes vote in MDBs. Likewise, the effect of $B R I$ membership when Chinese aid to DAC aid is 0 on US voting patterns in MDBs which is negative and statistically significant at the $1 \%$ level. Once we control for other control variables in column 2 and geographic regional dummies in column 3 , the interaction effect becomes statistically insignificant. However, it is important to note that the interpretation of the interaction term in non-linear models like the logit estimator is not similar to interpreting linear models. Consequently, a simple t-test on the coefficient of the interaction term is not sufficient to examine whether the interaction term is statistically significant or otherwise ( $\mathrm{Ai}$ and Norton 2003). We therefore rely on marginal plots. The interactive effect is best assessed with a margins plot which depicts the 
magnitude of the interaction effect from the model in Table 3, Column 2, in Figure 2. To calculate the marginal effect of BRI membership on US voting patterns in MDBs, we take into account both the conditioning variable (Chinese aid/DAC aid) and the interaction term and display graphically the total marginal effect conditional on Chinese aid/DAC aid. The y-axis of Figure 2 displays the marginal effect of BRI membership, and the marginal effect is evaluated on the Chinese aid/DAC aid variable on the $x$-axis. Note that we include the $90 \%$ confidence interval in Figure 2.

Table 3: Influence of BRI initiative on US voting patterns in MDBs: Interaction effects

\begin{tabular}{|c|c|c|c|}
\hline & $\begin{array}{c}\text { (1) } \\
\text { Yes vote }\end{array}$ & $\begin{array}{c}\text { (2) } \\
\text { Yes vote }\end{array}$ & $\begin{array}{c}(3) \\
\text { Yes vote }\end{array}$ \\
\hline Belt Road Initiative membership X Chinese aid/DAC aid & $\begin{array}{c}-0.0482 * * * \\
(0.0166)\end{array}$ & $\begin{array}{c}0.0215 \\
(0.0228)\end{array}$ & $\begin{array}{c}0.0289 \\
(0.0183)\end{array}$ \\
\hline Chinese aid/DAC aid & $\begin{array}{c}0.281^{* * *} \\
(0.104)\end{array}$ & $\begin{array}{c}0.349^{* * *} \\
(0.120)\end{array}$ & $\begin{array}{l}0.0298 \\
(0.165)\end{array}$ \\
\hline Belt Road Initiative membership & $\begin{array}{c}-0.0336 * * * \\
(0.0114)\end{array}$ & $\begin{array}{c}-0.0841^{* * *} \\
(0.0196)\end{array}$ & $\begin{array}{c}-0.0958 * * * \\
(0.0144)\end{array}$ \\
\hline Per capita GDP (log) & & $\begin{array}{c}-0.310^{* * *} \\
(0.0835)\end{array}$ & $\begin{array}{c}-0.423^{* * *} \\
(0.0864)\end{array}$ \\
\hline Population (log) & & $\begin{array}{l}-0.150 * * * \\
(0.0551)\end{array}$ & $\begin{array}{c}0.0104 \\
(0.0654)\end{array}$ \\
\hline Democracy Polity index & & $\begin{array}{c}0.00578 \\
(0.00915)\end{array}$ & $\begin{array}{l}0.0227^{* *} \\
(0.0107)\end{array}$ \\
\hline US Exports (log) & & $\begin{array}{l}0.158^{* * *} \\
(0.0413)\end{array}$ & $\begin{array}{c}0.0359 \\
(0.0557)\end{array}$ \\
\hline UNGA Voting alignment index & & $\begin{array}{l}0.767^{* *} \\
(0.330)\end{array}$ & $\begin{array}{c}0.392 \\
(0.354)\end{array}$ \\
\hline US Aid (log) & & $\begin{array}{l}-0.0192 * * \\
(0.00819)\end{array}$ & $\begin{array}{c}-0.0111 \\
(0.00839)\end{array}$ \\
\hline Civil conflict & & $\begin{array}{l}-0.157 \\
(0.114)\end{array}$ & $\begin{array}{l}-0.103 \\
(0.121)\end{array}$ \\
\hline East Asia dummy & & & $\begin{array}{l}1.121^{* * *} \\
(0.210)\end{array}$ \\
\hline South Asia dummy & & & $\begin{array}{c}0.110 \\
(0.201)\end{array}$ \\
\hline Europe \& Central Asia dummy & & & $\begin{array}{l}1.155^{* * *} \\
(0.197)\end{array}$ \\
\hline Latin America \& Caribbean dummy & & & $\begin{array}{l}1.057^{* * *} \\
(0.196)\end{array}$ \\
\hline MENA dummy & & & $\begin{array}{l}0.792^{* * *} \\
(0.200)\end{array}$ \\
\hline Constant & $\begin{array}{l}2.022^{* * *} \\
(0.0919)\end{array}$ & $\begin{array}{c}6.244^{* * *} \\
(1.245) \\
\end{array}$ & $\begin{array}{c}4.487^{* * *} \\
(1.309) \\
\end{array}$ \\
\hline Estimator & Logit & Logit & Logit \\
\hline Year Fixed Effects & Yes & Yes & Yes \\
\hline Number of MDBs & 16 & 16 & 16 \\
\hline Number of countries & 123 & 102 & 102 \\
\hline Total Observations & 5802 & 5,317 & 5,318 \\
\hline
\end{tabular}

Note:

(1) Standard errors in parenthesis.

(2) Statistical significance: ${ }^{* *} p<0.01,{ }^{* *} p<0.05,{ }^{*} p<0.1$ 
As seen in Figure 2, and in line with our theoretical expectations, BRI membership increases the probability of the US supporting loan projects at various MDBs (at the $90 \%$ confidence level at least) when the Chinese aid is lower than $40 \%$ of the total DAC aid in the recipient country.

Figure 2: BRI, China aid/DAC aid \& Marginal Effect on US voting pattern in MDBs

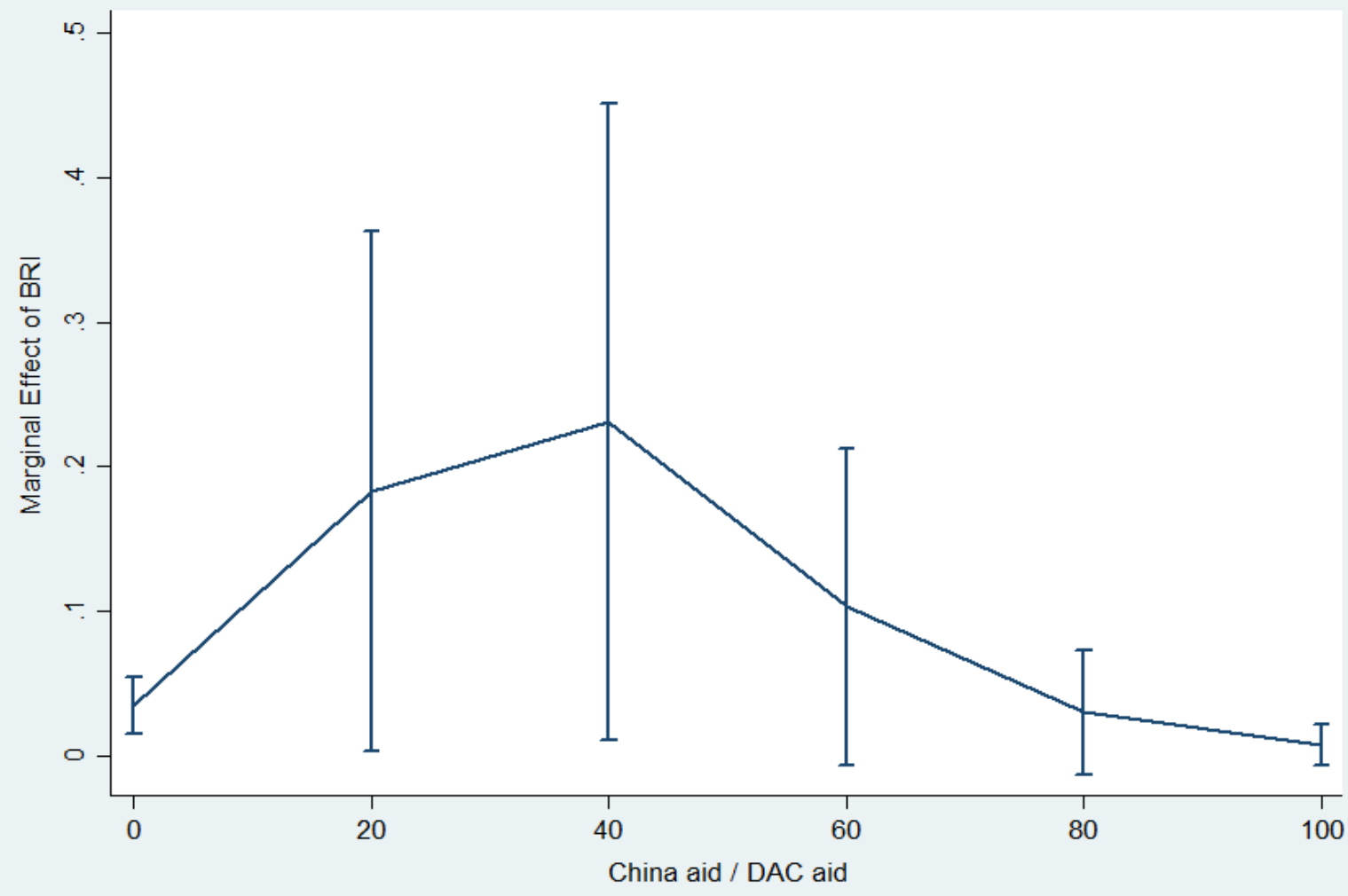

So, the marginal effects are significant and positive when the upper bound of the confidence interval is above zero. For instance, the marginal effects suggest that BRI membership increases the odds of the US voting in favor of a project at an MDB by $28 \%$ when the Chinese aid is at $40 \%$ of total DAC aid in that country. However, the margins plot also show that the effect of BRI membership on US voting pattern in MDBs is statistically insignificant once Chinese aid is $60 \%$ or more of the total DAC aid in the recipient country. At the maximum bound of Chinese aid to DAC aid, which is around $100 \%$, the effect of BRI member on the probability of US yes vote in an MDB is close to, and statistically indistinguishable from, zero. Interestingly, our conditional plot in Figure 2 shows an inverted $U$ shaped relationship between the effects of BRI membership on US yes vote in MDBs and Chinese aid to DAC aid suggesting that the US is competing for "in play" countries in a strategy comparable with the Cold War. Put differently, the BRI prompts the largest US response when China is engaged with the target country but not yet dominant.

A simple bivariate scatter plot between US voting pattern in the MDBs and Chinese aid shown in Figure 3 further corroborates our findings on 
interaction effects. The US vote scale in MDBs is measured on 0-2 in which 2 denotes a yes vote, while 1 is a no vote. Zero implies US abstention at the Executive Board of the Bank. As seen from both panels, countries which are major recipients of Chinese aid in absolute amount (right-side of the panel) and as a share of total DAC aid (left-side of the panel) are less likely to receive US support in the MDBs for their loan packages.

Figure 3: Relationship between China Aid and US voting pattern in MDBs, 2013-2018 period
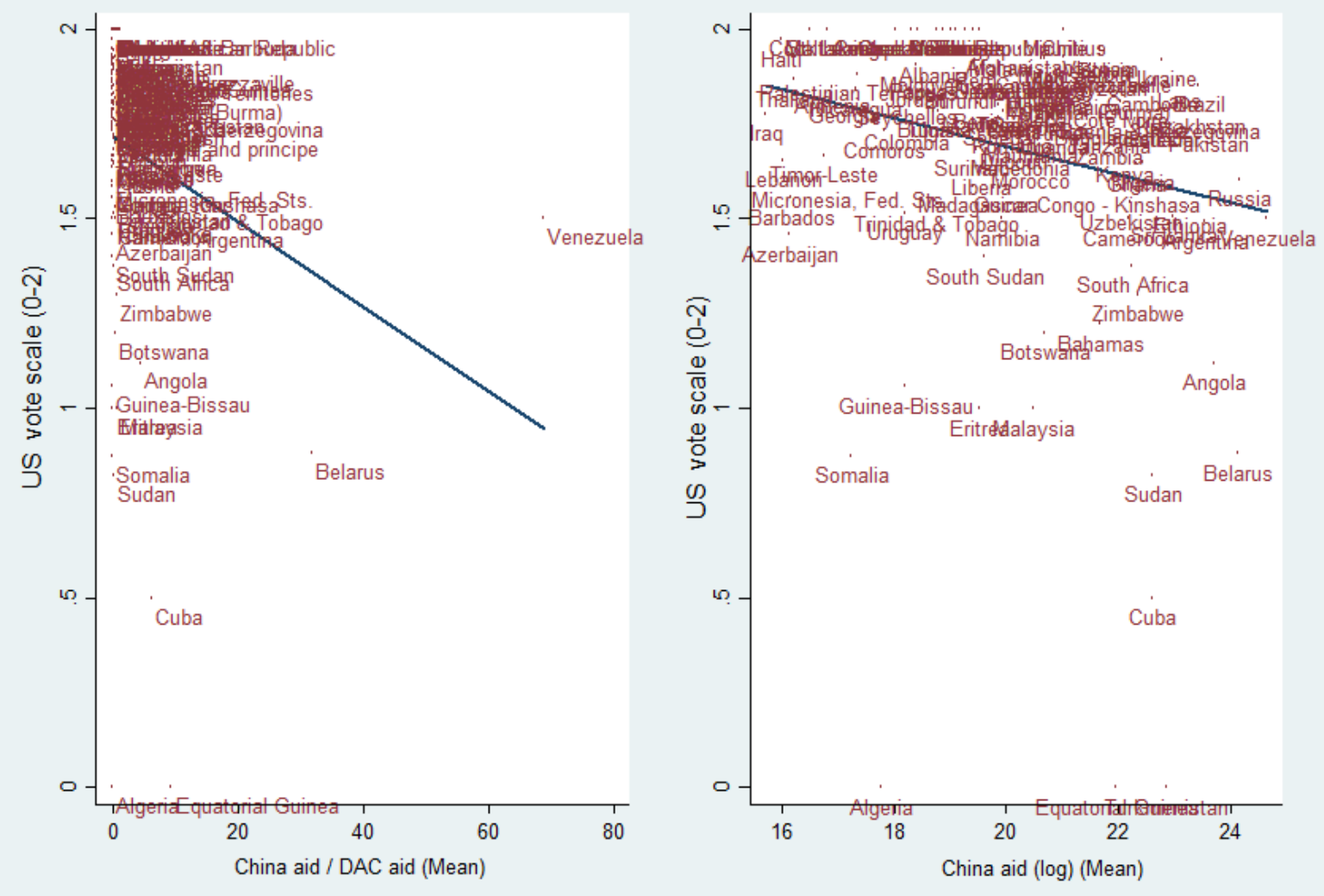

\subsection{Robustness Checks}

We examine the robustness of our findings in several ways. First, we use alternative definitions of $\mathrm{BRI}$ membership thus replacing our original measure with two variables. First is a version (2) which codes the value 1 purely based on joint statements listed by Foreign Affairs Ministry and 0 otherwise. Second, is a version (3) which simply takes the value 1 if a country has any document mentioning BRI in that particular year without providing further details on MoUs and 0 otherwise. We re-estimate all our models in Table 1-3 using both these alternative versions of BRI membership. Our results, reported in Table A1 in online appendix, remain robust to using these alternative measures of BRI.

Next, we use alternative estimation techniques to reassess our baseline estimations. It is noteworthy that voting options in the MDBs are partially 
ordered by the categories of 'no', 'abstain', and 'yes' votes. The ordinal nature of voting options available for the US in various MDBs allows us to utilize an ordered logit estimator controlling for year specific dummies. We create an ordinal measure of US voting in MDBs which takes the value 2 for an 'yes' vote, 1 for a 'no' vote and 0 for 'abstention'. Our results shown in Table A2 in online appendix find a positive effect of BRI membership on voting scale of US in the MDBs which is significantly different from zero at the $1 \%$ level. Interpreting coefficients from ordered logit estimator is not straightforward (Wooldridge 2002). We thus estimate marginal effects, or elasticities, at the mean values of all variables in the model, which then sums the impact of each variable to yield a prediction for the model at the mean values of all variables (a model prediction). We compute the marginal effects for vote scale value 2 (i.e. yes vote from the US). We then hold all other variables constant at their mean values and raise our main independent variable, BRI membership, to the value 1 . We find that the average prediction is increased by roughly $117 \%$ when a country is a BRI member. The interaction effect results also remains robust to using an ordered logit estimator.

Third, we use an alternative estimation technique in which we estimate our baseline models with OLS random effects. Our results presented in Table A3 remain robust to using OLS estimation technique. Fourth, we use a multinomial logit estimator since ordered logit might violate the parallel regression assumption (Long and Freese 2006, Long, 1997) because a 'yes' vote by the US denotes approval for the project while a 'no' vote and an 'abstention' indicate an intention against approval. Table $A 4$ in the online appendix shows the multinomial logit coefficient of a US 'no' vote compared to an 'yes' vote and of an abstention by the US compared to a 'yes' vote. The results show that BRI membership is significant for the abstention compared to 'yes' vote category only. However, BRI membership is not significant for a 'no' vote compared to the 'yes' vote category. This certainly suggest that the BRI plays some role in determining US voting in the MDBs. Specifically, the likelihood of US abstaining from voting on a loan package for BRI member country is significantly lower as opposed to supporting that country's proposal.

Fifth, we estimate the interaction effects by replacing Chinese aid/DAC aid with Chinese aid as a share of recipient country's GDP. Our new interaction effects show similar results as reported in Table 2. Specifically, we find that BRI membership increases the probability of US supporting MDB loan packages when Chinese aid is lower than $0.6 \%$ of the recipient country's GDP.

Sixth, we include range of other control variables into the model, including: a US sanctions dummy measure, an Egypt dummy, a US military alliance dummy, a Political Terror Scale human rights index, a State Failure index, 
a count of coup d'état incidents, and a Christian majority population dummy as previous studies find these variables to be determinants of US support for development aid projects (Kersting and Kilby 2016, Braaten 2014, Fleck and Kilby 2010, Rosenblum and Salehyan 2004, Alesina and Dollar, 2000, Apodaca and Stohl 1999, Alesina and Dollar 1998). The inclusion of other controls makes little difference to our original results presented in Tables 1 to 3 .

Seventh, we estimate a 2SLS-IV estimator and find that our instrumental variable results remain robust. Furthermore, we find that our instrument is relevant as the first stage regression models' F-statistics are well above the thumb rule of 10 (Bound, Jaeger and Baker 1995).

Finally, we are conscious of not overfitting our regression models. To address this problem, we adopt two approaches. First, we drop controls which are statistically insignificant in all our models (i.e., UNGA index and civil conflict dummy), retaining only those controls which are significant at conventional levels. Second, we re-estimate all our models dropping one control variable at a time. The basic results are not affected when we drop the variables which are statistically insignificant.

\section{Conclusion}

Our findings show strong support that the US backs country-programs in multilateral banks that directly respond to countries in China's Belt and Road initiative. This response is most pronounced in countries which are targeted by the BRI but where China is not yet the dominant financier. That the US response to is focus on these "in play" countries suggests the competitive nature of the US efforts. Thus, rather than the recent FOCAC/IDFC showdown heralding the start of Chinese/US strategic rivalry, it is merely the escalation of a dynamic that has already been years in development. These results are robust to a number of different variable formulations, specification choices and estimators.

Our findings have implications both for the political economy of development, but also for the broader international relations literatures. More narrowly, a return to strategic aid policies is likely to undermine the efficacy of contemporary development efforts. There is nearly universal consensus that the effectiveness of foreign aid to foster development and alleviate poverty are hampered by self-interested motivations of aid allocation. The emergence of these practices is especially concerning as the world grapples with the challenge of achieving the Sustainable Development Goals by 2030.

More broadly, our findings speak to the growing body of international relations scholarship casting light on the presence and nature of a systemic shift from a US-led unipolar order to a multi-polar world of competing political and social visions. The US response via MDBs to China's BRI makes evident that the 
former sees the latter as a revisionist power with whom to compete, if not confront, as opposed to an accommodating, cooperative partner. While competition in foreign aid remains in the realm of "soft power" the boundary with harder forms of material confrontation can often be blurry. Indeed, there are already signs that China is using the leverage gained through the BRI to achieve security objectives, including a recently established military base in Djibouti, and rumblings of further such installations in Sri Lanka, Pakistan, Vanuatu and Tonga. ${ }^{37}$

$37 \mathrm{https}$ //www.reuters.com/article/us-pacific-debt-tonga-graphic/tonga-pm-fears-asset-seizures-aspacific-debts-to-china-mount-idUSKBN1L10KM accessed 27-10-2018 http://www.atimes.com/chinas-base-in-sri-lanka-part-of-its-dominant-indian-ocean-presence/ accessed 27-10-2018

https://economictimes.indiatimes.com/news/defence/sri-lanka-rejects-us-claims-says-no-chinesemilitary-base-at-port/articleshow/66163389.cms accessed 27-10-2018 https://www.reuters.com/article/us-usa-china-djibouti/significant-consequences-if-china-takeskey-port-in-djibouti-u-s-general-idUSKCN1GI2V0 accessed 27-10-2018 


\section{References}

Achen, Christopher H. (2005). Let's Put the Garbage-Can Regressions and Garbage-Can Probits Where They Belong. Conflict Management and Peace Science, 22(4), 327-39

Ai, C., and Norton, E. (2003). Interaction Terms in Logit and Probit Models. Economics Letters, 80, 123-129.

Alesina, Alberto, and David Dollar (2000). Who gives foreign aid to whom and why? Journal of Economic Growth, 5(1), 33-63.

Alesina, Alberto and David Dollar (1998). Who gives foreign aid to whom and why? Journal of Economic Growth, 5(1), 33-64.

Andersen, Thomas Barnebeck, Henrik Hansen and Thomas Markussen (2006). US politics and World Bank IDA-lending. Journal of Development Studies, 42(5), 772-794.

Apodaca, Clair and Michael Stohl (1999). United States human rights policy and foreign assistance. International Studies Quarterly, 43(1), 185-198.

Baker McKenzie. (2017). Belt \& Road: Opportunity \& Risk: The prospects and perils of building China's New Silk Road. Available at: https://www.bakermckenzie.com//media/files/insight/publications/2017/10/beltroad/baker mckenzie belt road report 2017.pdf?la=en

Bastos, Paulo (2018). Exposure of Belt and Road Economies to China Trade Shocks Policy. Research Working Paper 8503, The World Bank: Washington D.C.

Bearce, D., \& Tirone, D. (2010). Foreign Aid Effectiveness and the Strategic Goals of Donor Governments. The Journal of Politics, 72(3), 837-851

Beck, Nathaniel. (2001). Time-Series-Cross-Section Data: What Have We Learned in the Past Few Years. Annual Review of Political Science, 4, 271-93

Bermeo, S. B. (2017). Aid Allocation and Targeted Development in an Increasingly Connected World. International Organization, 71(4), 735-766.

Berthélemy, J. C., \& Tichit, A. (2004). Bilateral donors' aid allocation decisions-a three-dimensional panel analysis. International Review of Economics \& Finance, 13(3), 253-274

Bitzer, Jürgen and Erkan Gören. (2018) Foreign Aid and Subnational Development: A Grid Cell Analysis. AidData Working Paper \#55. Williamsburg, VA: AidData at William \& Mary.

Blair, Robert A., and Philip Roessler. The Effects of Chinese Aid on State Legitimacy in Africa: Cross-National and Sub-National Evidence from Surveys, Survey Experiments, and Behavioral Games. AidData Working Paper \#59. Williamsburg, VA: AidData at William \& Mary. 
Bound, J., Jaeger, D., \& Baker, R. (1995). Problems with instrumental variables estimation when the correlation between the instruments and the endogenous explanatory variable is weak. Journal of American Statistical Association, 90, 443-450

Brady, Anne-Marie (2015) China's Foreign Propaganda Machine. Journal of Democracy 26(4): 51-59.

Braaten, Daniel B. (2014). Determinants of US foreign policy in multilateral development banks: The place of human rights. Journal of Peace Research, 51(4), 515-527.

Brazys, Samuel Rueckert and Vadlamannati, Krishna Chaitanya (2018). Aid Curse with Chinese Characteristics? Chinese Development Flows and Economic Reforms. GLOBUS Working Research Paper, Available at: http://dx.doi.org/10.2139/ssrn.3157492

Brazys, S., \& Dukalskis, A. (2017). Canary in the coal mine? China, the UNGA, and the changing world order. Review of International Studies, 43(4), 742-764.

Brazys, S., Elkink, J. A., and Kelly, G. (2017). Bad neighbors? How co-located Chinese and World Bank development projects impact local corruption in Tanzania. The Review of International Organizations, 12(2), 227-253.

Briggs, R. C. (2017). Does foreign aid target the poorest?. International Organization, 71(1), 187-206.

Bureau of Economic Affairs (2018). BEA foreign trade statistics. available at: https://www.bea.gov/data/intl-trade-investment/international-tradegoods-and-services

Buzan, Barry (2014) The Logic and Contradictions of 'Peaceful Rise/Development' as China's Grand Strategy. Chinese Journal of International Politics 7(4): 381-420.

Cai, P. (2017). Understanding China's belt and road initiative, Lowy Institute For International Policy.

Callahan, William A. (2016) China's 'Asia Dream': The Belt and Road Initiative and the New Regional Order. Asian Journal of Comparative Politics 1(3): 226243.

Chan, S. (2018). The Belt and Road Initiative: Implications for China and East Asian Economies. The Copenhagen Journal of Asian Studies, 35, 52-78

Chamberlain, G., (1980). Analysis of Covariance with Qualitative Data. Review of Economic Studies, 47, 225-238

Cheibub, José A., Gandhi, J., and Vreeland J. R. (2010). Democracy and Dictatorship Revisited. Public Choice, 143(2-1), 67-101

Chin, H. and He, W. (2016). The Belt and Road Initiative: 65 Countries and Beyond. Hong Kong: Fung Business Intelligence Center. Available at: 
https://www.fbicgroup.com/sites/default/files/B\%26R Initiative 65 Cou ntries and Beyond.pdf

Demirel-Pegg, Tijen and James Moskowitz (2009). US aid allocation: The nexus of human rights, democracy, and development. Journal of Peace Research, 46(2), 181-198.

Dreher, A., Fuchs, A., Parks, B., Strange, A. M., and Tierney, M. J. (2018a). Apples and dragon fruits: the determinants of aid and other forms of state financing from China to Africa. International Studies Quarterly, 62(1), 182194

Dreher, Axel. Lang, Valentin F., Rosendorff, Peter B., and Vreeland, James R. (2018b). Buying Votes and International Organizations: The Dirty WorkHypothesis. CESifo Working Paper Series 7329, CESifo Group Munich.

Dreher, A., Fuchs, A., Parks, B., \& Strange, A. M. (2017). Aid, China, and Growth: Evidence from a New Global Development Finance Dataset. AidData Working Paper \#46. Williamsburg, VA: AidData.

Dreher, Axel; Lohmann, Steffen. (2015). Aid and growth at the regional level. Oxford Review of Economic Policy, 31(3-4), 420-446.

Dreher, Axel, Jan-Egbert Sturm, and James Raymond Vreeland. (2009a). Development Aid and International Politics: Does membership on the UN Security Council influence World Bank decisions? Journal of Development Economics, 88(1),1-18.

Dreher, Axel, Jan-Egbert Sturm, and James Raymond Vreeland. (2009b). Global Horse Trading: IMF Loans for Votes in the United Nations Security Council. European Economic Review, 53(7), 742-57.

Dreher, Axel, and Jan-Egbert Sturm (2012). Do the IMF and the World Bank influence voting in the UN General Assembly? Public Choice, 151(1), 363397.

Du, Julan and Yifei Zhang (2018). Does One Belt One Road initiative promote Chinese overseas direct investment? China Economic Review, 47, 189205.

Dunning, T. (2004). Conditioning the Effects of Aid: Cold War Politics, Donor Credibility, and Democracy in Africa. International Organization, 58(2), 409-423.

Economy, Elizabeth C. (2018). The Third Revolution: Xi Jinping and the New Chinese State. Oxford: Oxford University Press.

Edney, Kingsley (2014). The Globalization of Chinese Propaganda: International Power and Domestic Political Cohesion. New York: Palgrave MacMillan.

Eisenman, Joshua and Devin T. Stewart (2017). China's New Silk Road is Getting Muddy. Foreign Policy 9 January 2017. Available at: 
https://foreignpolicy.com/2017/01/09/chinas-new-silk-road-is-gettingmuddy/ (accessed 30 October 2018).

Fawcett, Tom. (2006). An Introduction to Roc Analysis. Pattern Recognition Letters, 27, 861-74.

Feaver, Peter (2009) What is a Grand Strategy and Why Do We Need It? Foreign Policy 8 April 2009. Available at: https://foreignpolicy.com/2009/04/08/what-is-grand-strategy-and-whydo-we-need-it/ (accessed 30 October 2018).

Ferdinand, Peter (2016). Westward Ho - The China Dream and 'One Belt, One Road': Chinese Foreign Policy Under Xi Jinping. International Affairs, 92(4), 941-957.

Fleck, R.K., Kilby, C., (2006). World Bank Independence: A Model and Statistical Analysis of US Influence. Review of Development Economics, 10(2), 224 240.

Foot, R. (2006). Chinese Strategies in a US-Hegemonic Global Order: Accommodating and Hedging. International Affairs, 82(1), 77-94.

Gleditsch, N. P., Wallensteen, P., Eriksson, M., Sollenberg, M. and Strand, H. (2002) Armed Conflict 1946-2001: A New Dataset, Journal of Peace Research 39(5): 615-637.

Goddard, Stacie E. and Ronald R. Krebs (2015). Rhetoric, Legitimation, and Grand Strategy. Security Studies 24(1), 5-36.

Goldstein, Avery (2005). Rising to the Challenge: China's Grand Strategy and International Security. Palo Alto, CA: Stanford University Press.

Griffin, K. (1991). Foreign Aid after the Cold War. Development and Change, 22, 645-685

Gurr, Ted Robert and Keith Jaggers. (1995). Tracking Democracy's Third Wave with the Polity II Data. Journal of Peace Research, 32(4), 469-82.

Hall, S. (2011). Managing tied aid competition: Domestic politics, credible threats, and the Helsinki disciplines. Review of International Political Economy, 18(5), 646-672.

Harrigan, J., \& Wang, C. (2011). A new approach to the allocation of aid among developing countries: is the USA different from the rest?. World Development, 39(8), 1281-1293.

Heilmann, Sebastian and Dirk H. Schmidt (2014) China's Foreign and Economic Relations: An Unconventional Global Power. Lanham, MD: Rowman \& Littlefield.

Hernandez, D. (2017). Are "New" Donors Challenging World Bank Conditionality?. World Development, 96, 529-549.

Hillman, Jonathan E. (2018) China's Belt and Road is Full of Holes. Center for Strategic \& International Studies Briefs, September 2018. 
Huang, Yiping (2016). Understanding China's Belt \& Road Initiative: Motivation, framework and assessment. China Economic Review, 40, 314-321.

Hurley, J., Morris, S. and Portelance, G. (2018). Examining the Debt Implications of the Belt and Road Initiative from a Policy Perspective. Policy paper 212, Center for global Development: Washington D.C.

Isaksson, Ann-S., and Kotsadam, A. (2016). Chinese Aid and Local Corruption. AidData Working Paper \#33. AidData, Williamsburg, VA

Jiangtao, Shi (2018). US competes with China's 'Belt and Road Initiative' with US\$113 million Asian investment programme. South China Morning Post (SCMP), Available at: https://www.scmp.com/news/china/economy/article/2157381/uscompetes-chinas-belt-and-road-initiative-new-asian-investment

Kersting, Erasmus K. and Christopher Kilby (2016). With a little help from my friends: Global electioneering and World Bank lending. Journal of Development Economics, 121, 153-165.

Khong, Y. F. (2014). Primacy or World Order? The United States and China's Rise-A Review Essay. International Security, 38(3), 153-175

Kilby, Christopher (2006). Donor influence in multilateral development banks: The case of the Asian Development Bank. Review of International Organizations, 1(2), 173-195.

Lai, Brian (2003). Examining the goals of US foreign assistance in the post-Cold War period, 1991-96. Journal of Peace Research, 40(1), 103-128.

Lancaster, Tony (2000). The Incidental Parameter Problem since 1948. Journal of Econometrics, 95, 391-413

Lawson, Marian L. and Susan B. Epstein (2017). Democracy Promotion: An Objective of U.S. Foreign Assistance. CRS report no. R44858, Congressional Research Service: Washington D.C.

Layne, Christopher (2018). The US-Chinese power shift and the end of the Pax Americana. International Affairs, 94(1), 89-111.

Long, J Scott (1997). Regression Models for Categorical and Limited Dependent Variables. Thousand Oaks, CA: Sage.

Long, J Scott and Jeremy Freese (2006). Regression Models for Categorical Dependent Variables Using Stata. $3^{\text {rd }}$ Edition, STATA Press: Texas.

Lundborg, P. (1998). Foreign aid and international support as a gift exchange. Economics \& Politics, 10(2), 127-142.

Martorano, B., Metzger, L., \& Sanfilippo, M. (2018). Chinese development assistance and household welfare in sub-Saharan Africa. UNU-MERIT Working Paper Series, 2018.

Mauro Boffa (2018). Trade Linkages between the Belt and Road Economies. Policy Research Working Paper 8423, The World Bank: Washington D.C. 
McKinley, R. D., \& Little, R. (1977). A foreign policy model of US bilateral aid allocation. World Politics, 30(1), 58-86.

McKinley, R. D., \& Little, R. (1979). The US aid relationship: a test of the recipient need and the donor interest models. Political Studies, 27(2), 236-250.

Meernik, James, Eric L. Krueger, and Steven C. Poe. (1998). Testing Models of U.S. Foreign Policy: Foreign Aid during and after the Cold War. Journal of Politics, 60 (1), 63-85

Meltzer Joshua P. (2017). The U.S.-China trade agreement-a huge deal for China. The Brookings Institute, Available at: https://www.brookings.edu/blog/order-from-chaos/2017/05/15/the-u-schina-trade-agreement-a-huge-deal-for-china/

Morrison, K. (2011). As the World Bank Turns: Determinants of IDA Lending in the Cold War and After. Business and Politics, 13(2), 1-27.

Nathan, Andrew J. and Andrew Scobell (2012). China's Search for Security. New York: Columbia University Press.

Nordin, Astrid H. M. and Weissmann, Mikael (2018) Will Trump make China great again? The belt and road initiative and international order. International Affairs, 94(2), 231-249.

Peterson, Timothy M. and James M. Scott (2018). The Democracy Aid Calculus: Regimes, Political Opponents, and the Allocation of US Democracy Assistance, 1981-2009. International Interactions, 44(2), 268-293.

Poh, Angela and Mingjiang Li (2017). A China in Transition: The Rhetoric and Substance of Chinese Foreign Policy under Xi Jinping. Asian Security, 13(2), 84-97.

Ramchandran, Sudha (2018). The Maldives' New Government: Mission Impossible? The Diplomat 1 October 2018. Available at: https://thediplomat.com/2018/10/the-maldives-new-governmentmission-impossible/ (accessed 30 October 2018).

Rolland, Nadège (2017a). China's Eurasian Century? Political and Strategic Implications of the Belt and Road Initiative. Washington: National Bureau of Asian Research.

Rolland, Nadège (2017b). China's 'Belt and Road Initiative': Underwhelming or Game-Changer? The Washington Quarterly, 40(1), 127-142.

Rosenblum, Marc R and Idean Salehyan (2004). Norms and interests in US asylum enforcement. Journal of Peace Research, 41(6), 677-697.

Schrodt, Philip A. (2014). Seven Deadly Sins of Contemporary Quantitative Political Analysis. Journal of Peace Research, 51(2), 287-300.

Schweller, Randall L. and Xiaoyu Pu (2011). After Unipolarity: China's Visions of International Order in an Era of US Decline. International Security, 36(1), 41-72. 
Shen, Simon and Wilson Chan (2018). A comparative study of the Belt and Road Initiative and the Marshall plan, Palgrave Communications. 4(1), 1-11,

Shen, Simon (2016). How China's 'Belt and road' compares to the Marshall plan. The Diplomat, Available at: http://thediplomat.com/2016/02/how-chinas-belt-and-roadcompares-to-the-marshall-plan/

Strand, Jonathan R. and Zappile, Tina M. (2015). Always Vote for Principle, Though You May Vote Alone: Explaining United States Political Support for Multilateral Development Loans. World Development, 72(C), 224-239.

Strange, A. M., Dreher, A., Fuchs, A., Parks, B., and Tierney, M. J. (2017). Tracking underreported financial flows: China's development finance and the aidconflict nexus revisited. Journal of Conflict Resolution, 61(5), 935-963.

Strezhnev, Anton and Erik Voeten (2012). United Nations General Assembly Voting Data. Available at: http://hdl.handle.net/1902.1/12379

Swedlund, Helly (2017). Can foreign aid donors credibly threaten to suspend aid? Evidence from a cross-national survey of donor officials. Review of International Political Economy, 24(3), 454-496.

The Ministry of Foreign Affairs of the People's Republic of China (2018). Communiques and joint statement of Ministry of Foreign Affairs, (中国外 交部---声明公报)， Available at: http://www.fmprc.gov.cn/web/ziliao 674904/1179 674909/

The Ministry of Foreign Affairs of the People's Republic of China (2018). Belt Road Initiative, Ministry of Foreign Affairs, (中国外交部---新闻/重要新闻 /一带一路专栏下的重要新闻), Available at: http://www.fmprc.gov.cn/mfa chn//ziliao 611306/zt 611380/dnzt 611 382/ydyl 667839/zyxw 667918/

The Ministry of Foreign Affairs of the People's Republic of China (2018). Country Profiles, Ministry of Foreign Affairs (中国外交部一国家地区一该国家的 重要文件或者重要新闻), Available at: https://www.fmprc.gov.cn/web/gihdq 676201/gi 676203/oz 678770/1 206 678772/1207 678784/

Tsai, Wen-Hsuan (2017). Enabling China's Voice to Be Heard by the World: Ideas and Operations of the Chinese Communist Party's External Propaganda System. Problems of Post-Communism, 64(3-4), 203-213.

United States Department of Treasury (2018). Loan Review Votes. Available at: http://www.treasury.gov/resource-center/international/developmentbanks/Pages/data.aspx 
Voeten, Erik (2004). Resisting the Lonely Superpower: Responses of States in the UN to U.S. Dominance. The Journal of Politics, 66(3), 729-754.

Voeten, Erik (2000). Clashes in the Assembly. International Organization, 54(2), 185-215.

Wang, Y. (2016). Offensive for defensive: The belt and road initiative and China's new grand strategy. The Pacific Review, 29(3), 455-463.

Wang, Jisi (2011) China's Search for a Grand Strategy: A Rising Great Power Finds Its Way. Foreign Affairs March/April 2011, 68-79.

Wooldridge, Jeffrey (2002). Econometric Analysis of Cross Section and Panel Data, MIT Press.

World Bank. (2018). World Development Indicators 2018. in online database: http://data.worldbank.org/products/wdi. Washington, DC: World Bank.

$\mathrm{Yu}, \mathrm{H}$. (2017). Motivation behind China's 'One belt, one road' initiatives and establishment of the Asian Infrastructure Investment Bank. Journal of Contemporary China, 26(105), 353-368.

Zhang, Jian (2015). China's New Foreign Policy Under Xi Jinping: Towards 'Peaceful Rise 2.0'? Global Change, Peace \& Security, 27(1), 5-19.

Zhai, Fan (2018). China's belt and road initiative: A preliminary quantitative assessment. Journal of Asian Economics, 55, 84-92 


\section{Appendices}

Appendix 1: List of countries

\begin{tabular}{|c|c|c|c|}
\hline Afghanistan & Dominica & Macedonia & Serbia \\
\hline Albania & Dominican Republic & Madagascar & Seychelles \\
\hline Algeria & Ecuador & Malawi & Sierra Leone \\
\hline Angola & Egypt & Malaysia & Slovakia \\
\hline Antigua \& Barbuda & El Salvador & Maldives & Slovenia \\
\hline Argentina & Equatorial Guinea & Mali & Solomon Islands \\
\hline Armenia & Eritrea & Malta & Somalia \\
\hline Azerbaijan & Estonia & Marshall Islands & South Africa \\
\hline Bahamas & Ethiopia & Mauritania & South Sudan \\
\hline Bangladesh & Fiji & Mauritius & Sri Lanka \\
\hline Barbados & Gabon & Mexico & St. Lucia \\
\hline Belarus & Gambia & Micronesia, Fed. Sts. & St. Vincent \& Grenadines \\
\hline Belize & Georgia & Moldova & Sudan \\
\hline Benin & Ghana & Mongolia & Suriname \\
\hline Bhutan & Greece & Montenegro & Swaziland \\
\hline Bolivia & Grenada & Morocco & Sao Tome and Principe \\
\hline Bosnia \& Herzegovina & Guatemala & Mozambique & Tajikistan \\
\hline Botswana & Guinea & Myanmar (Burma) & Tanzania \\
\hline Brazil & Guinea-Bissau & Namibia & Thailand \\
\hline Bulgaria & Guyana & Nauru & Timor-Leste \\
\hline Burkina Faso & Haiti & Nepal & Togo \\
\hline Burundi & Honduras & Nicaragua & Tonga \\
\hline Cambodia & Hungary & Niger & Trinidad \& Tobago \\
\hline Cameroon & India & Nigeria & Tunisia \\
\hline Cape Verde & Indonesia & Oman & Turkey \\
\hline Central African Republic & Iraq & Pakistan & Turkmenistan \\
\hline Chad & Jamaica & Palau & Tuvalu \\
\hline Chile & Jordan & Palestinian Territories & Uganda \\
\hline China & Kazakhstan & Panama & Ukraine \\
\hline Colombia & Kenya & Papua New Guinea & Uruguay \\
\hline Comoros & Kiribati & Paraguay & Uzbekistan \\
\hline Congo - Brazzaville & Kosovo & Peru & Vanuatu \\
\hline Congo - Kinshasa & Kyrgyzstan & Philippines & Venezuela \\
\hline Cook Islands & Laos & Poland & Vietnam \\
\hline Costa Rica & Latvia & Romania & Yemen \\
\hline Croatia & Lebanon & Russia & Zambia \\
\hline Cuba & Lesotho & Rwanda & Zimbabwe \\
\hline Cyprus & Liberia & Samoa & \\
\hline Cote d' Ivoire & Libya & Saudi Arabia & \\
\hline Djibouti & Lithuania & Senegal & \\
\hline
\end{tabular}


Appendix 2: List of MDBs in study

\begin{tabular}{l}
\hline The World Bank \\
International Development Agency \\
European Bank for Resounstruction and Developmet \\
Asian Development Bank \\
African Development Bank \\
Inter American Development Bank \\
The International Monetary Fund \\
The Global Environment Facility, WB \\
The International Fund for Agricultural Development \\
The Climate Investment Funds \\
The Green Climate Funds
\end{tabular} 
Appendix 3: List of countries with BRI membership year

\begin{tabular}{|c|c|c|c|}
\hline Country & Year & Country & Year \\
\hline Afghanistan & 2014 & Latvia & 2016 \\
\hline Albania & 2017 & Moldova & 2015 \\
\hline United Arab Emirates & 2015 & Maldives & 2014 \\
\hline Armenia & 2015 & Macedonia & 2015 \\
\hline Azerbaijan & 2015 & Myanmar & 2014 \\
\hline Bangladesh & 2016 & Montenegro & 2017 \\
\hline Bulgaria & 2015 & Mongolia & 2014 \\
\hline Bahrain & 2016 & Malaysia & 2015 \\
\hline Bosnia and Herzegovina & 2017 & Nepal & 2014 \\
\hline Belarus & 2014 & Oman & 2014 \\
\hline Brunei & 2014 & Pakistan & 2014 \\
\hline Bhutan & 2015 & Philippines & 2017 \\
\hline Cyprus & 2015 & Poland & 2015 \\
\hline Czech Republic & 2015 & Palestine & 2017 \\
\hline Egypt & 2016 & Qatar & 2014 \\
\hline Estonia & 2017 & Romania & 2015 \\
\hline Georgia & 2015 & Russia & 2015 \\
\hline Croatia & 2017 & Saudi Arabia & 2014 \\
\hline Hungary & 2015 & Singapore & 2015 \\
\hline Indonesia & 2015 & Serbia & 2015 \\
\hline India & 2014 & Slovakia & 2015 \\
\hline Iran & 2016 & Slovenia & 2017 \\
\hline Iraq & 2015 & Syria & 2017 \\
\hline Israel & 2017 & Thailand & 2017 \\
\hline Jordan & 2015 & Tajikistan & 2014 \\
\hline Kazakhstan & 2013 & Turkmenistan & 2014 \\
\hline Kyrgyzstan & 2014 & Timor-Leste & 2014 \\
\hline Cambodia & 2016 & Turkey & 2015 \\
\hline Kuwait & 2014 & Ukraine & 2016 \\
\hline Laos & 2016 & Uzbekistan & 2014 \\
\hline Lebanon & 2017 & Vietnam & 2015 \\
\hline Sri Lanka & 2014 & Yemen & 2016 \\
\hline Lithuania & 2017 & & \\
\hline
\end{tabular}


Appendix 4: Descriptive statistics

\begin{tabular}{lccccc}
\hline \multicolumn{1}{c}{ Variables } & Mean & Standard Deviation & Minimum & Maximum & Observations \\
\hline US Yes vote & 0.854 & 0.353 & 0.000 & 1.000 & 6,973 \\
Belt Road initiative & 0.253 & 0.435 & 0.000 & 1.000 & 6,975 \\
Per capita GDP (log) & 8.007 & 1.075 & 5.386 & 10.256 & 6,938 \\
Population (log) & 17.053 & 1.947 & 9.280 & 21.050 & 6,963 \\
Democracy Polity index & 4.258 & 5.455 & -10.000 & 10.000 & 6,571 \\
US Exports (log) & 7.075 & 2.611 & -1.615 & 12.401 & 6,876 \\
UNGA Voting alignment index & 0.353 & 0.186 & 0.000 & 1.000 & 6,849 \\
US Aid (log) & 19.219 & 6.301 & 0.000 & 24.972 & 6,644 \\
Civil conflict & 0.205 & 0.404 & 0.000 & 1.000 & 6,975 \\
\hline
\end{tabular}


Appendix 5: Data sources and Definitions

\begin{tabular}{|c|c|}
\hline Variables & Data definition and sources \\
\hline US Yes vote dummy & $\begin{array}{l}\text { Takes the value } 1 \text { if US votes in approval for the project under consideration in } \\
\text { the Executive Board of each MDB and } 0 \text { otherwise. The information on US voting } \\
\text { pattern in each MDB is sourced from the US Treasury Department which is } \\
\text { available in public domain on its website since } 2004 \text { (2018). }\end{array}$ \\
\hline Belt Road Initiative dummy & $\begin{array}{l}\text { Takes the value } 1 \text { if country } i \text { in year } t \text { joined the BRI program and } 0 \text { otherwise. } \\
\text { The information on BRI membership is sourced from three different sources } \\
\text { namely, official declarations and communiques of China's Foreign Affairs Ministry, } \\
\text { i.e., 中国外交部---新闻/重要新闻/一带一路专栏下的重要新闻, each country's } \\
\text { profile in the Ministry of Foreign Affairs of China, i.e., 中国外交部一国家地区一 } \\
\text { 该国家的重要文件或者重要新闻, and, The State Council (chaired by the Premier } \\
\text { and includes the heads of each of the cabinet-level executive departments), } \\
\text { Ministry of Commerce of China, and Department of National Development and } \\
\text { Reform Commission (DNDRC) }\end{array}$ \\
\hline Chinese aid/DAC aid & $\begin{array}{l}\text { Aid flows including ODA and OOF -type flows measured in US\$ constant prices } \\
\text { and is sourced from the AidData's Global Chinese Official Finance Dataset, version } \\
1.0 \text { (AidData 2017) developed by Dreher, Fuchs, Parks, Strange, and Tierney } \\
\text { (2017) which is divided with recipient country's aid from Development Assistance } \\
\text { Committee (DAC) donors measured in US\$ constant prices and is sourced from } \\
\text { the World Development Indicators, } 2018\end{array}$ \\
\hline & GDP per head in 2000 US\$ constant prices sourced from the World Development \\
\hline Per capita GDP (log) & Indicators (WDI) 2017, World Bank. \\
\hline Population (log) & $\begin{array}{l}\text { Count of total population (log) sourced from World Development Indicators 2018, } \\
\text { World Bank. }\end{array}$ \\
\hline Democracy Polity index & $\begin{array}{l}\text { Polity IV, polity2 index coded on the scale of }-10 \text { to }+10 \text { where highest value } \\
\text { implies full democracy lagged by a year sourced from Gurr (2002) }\end{array}$ \\
\hline US exports (log) & $\begin{array}{l}\text { US exports to country } i \text { logged which is measured in US\$ current prices and is } \\
\text { obtained from the international trade statistics of the Bureau of Economic } \\
\text { Analysis, } 2018\end{array}$ \\
\hline UNGA voting index & $\begin{array}{l}\text { Codes votes in agreement with the US as } 1 \text {, in disagreement as } 3 \text {, and } 2 \text { for } \\
\text { abstentions. The resulting numbers are divided by total number of votes in the } \\
\text { UNGA, resulting in a measure coded between } 0 \text { and 1, sourced from Strezhnev } \\
\text { and Voeten (2012) and is updated until } 2017\end{array}$ \\
\hline US aid (log) & $\begin{array}{l}\text { Total US aid to country } i \text { logged measured in US\$ constant prices and is sourced } \\
\text { from the World Development Indicators, } 2018\end{array}$ \\
\hline Civil war dummy & $\begin{array}{l}\text { Dummy coded } 1 \text { for year } t \text { in country } i \text { has at least one active conflict with } 25 \\
\text { battle deaths and } 0 \text { otherwise obtained from Uppsala Armed Conflict Dataset } \\
\text { Version 4- } 2018\end{array}$ \\
\hline
\end{tabular}




\title{
ONLINE APPENDIX
}

\author{
Robustness Tests
}


Robustness Table A1: Influence of BRI initiative on US voting patterns in MDBs: Alternative BRI measures

\begin{tabular}{|c|c|c|c|c|}
\hline & $\begin{array}{c}\text { (1) } \\
\text { Yes vote }\end{array}$ & $\begin{array}{c}(2) \\
\text { Yes vote }\end{array}$ & $\begin{array}{c}\text { (3) } \\
\text { Yes vote }\end{array}$ & $\begin{array}{c}(4) \\
\text { Yes vote }\end{array}$ \\
\hline Belt Road initiative membership (version 2) & $\begin{array}{c}0.684^{* * *} \\
(0.119)\end{array}$ & & $\begin{array}{c}0.337^{* * *} \\
(0.130)\end{array}$ & \\
\hline Belt Road initiative membership (version 3) & & $\begin{array}{c}0.708^{* * *} \\
(0.113)\end{array}$ & & $\begin{array}{c}0.401^{* * *} \\
(0.139)\end{array}$ \\
\hline Per capita GDP (log) & $\begin{array}{c}-0.654^{* * *} \\
(0.0697)\end{array}$ & $\begin{array}{c}-0.686^{* * *} \\
(0.0715)\end{array}$ & $\begin{array}{c}-0.859^{* * *} \\
(0.0863)\end{array}$ & $\begin{array}{c}-0.865^{* * *} \\
(0.0861)\end{array}$ \\
\hline Population (log) & $\begin{array}{c}-0.397^{* * *} \\
(0.0474)\end{array}$ & $\begin{array}{c}-0.416^{* * *} \\
(0.0492)\end{array}$ & $\begin{array}{l}-0.295^{* * *} \\
(0.0657)\end{array}$ & $\begin{array}{c}-0.291^{* * *} \\
(0.0660)\end{array}$ \\
\hline Democracy Polity index & $\begin{array}{l}0.0634^{* * *} \\
(0.00700)\end{array}$ & $\begin{array}{l}0.0585^{* * *} \\
(0.00684)\end{array}$ & $\begin{array}{l}0.0776^{* * *} \\
(0.00858)\end{array}$ & $\begin{array}{l}0.0768^{* * *} \\
(0.00848)\end{array}$ \\
\hline US Exports (log) & $\begin{array}{l}0.238^{* * *} \\
(0.0369)\end{array}$ & $\begin{array}{l}0.246^{* * *} \\
(0.0378)\end{array}$ & $\begin{array}{l}0.194^{* * *} \\
(0.0556)\end{array}$ & $\begin{array}{l}0.185^{* * *} \\
(0.0560)\end{array}$ \\
\hline UNGA Voting alignment index & $\begin{array}{c}0.857^{* * *} \\
(0.311)\end{array}$ & $\begin{array}{c}0.997^{* * *} \\
(0.308)\end{array}$ & $\begin{array}{c}0.458 \\
(0.350)\end{array}$ & $\begin{array}{c}0.519 \\
(0.350)\end{array}$ \\
\hline US Aid (log) & $\begin{array}{c}-0.0330^{* * *} \\
(0.00767)\end{array}$ & $\begin{array}{c}-0.0341^{* * *} \\
(0.00758)\end{array}$ & $\begin{array}{c}-0.0307^{* * *} \\
(0.00846)\end{array}$ & $\begin{array}{c}-0.0306^{* * *} \\
(0.00839)\end{array}$ \\
\hline Civil conflict & $\begin{array}{c}0.341^{* * *} \\
(0.104)\end{array}$ & $\begin{array}{c}0.257^{* *} \\
(0.105)\end{array}$ & $\begin{array}{l}0.216^{*} \\
(0.114)\end{array}$ & $\begin{array}{l}0.195^{*} \\
(0.115)\end{array}$ \\
\hline East Asia dummy & & & $\begin{array}{c}0.209 \\
(0.168)\end{array}$ & $\begin{array}{c}0.246 \\
(0.166)\end{array}$ \\
\hline South Asia dummy & & & $\begin{array}{c}0.00825 \\
(0.179)\end{array}$ & $\begin{array}{r}-0.0871 \\
(0.193)\end{array}$ \\
\hline Europe \& Central Asia dummy & & & $\begin{array}{c}0.759^{* * *} \\
(0.192)\end{array}$ & $\begin{array}{c}0.715^{* * *} \\
(0.193)\end{array}$ \\
\hline Latin America \& Caribbean dummy & & & $\begin{array}{c}0.325 \\
(0.223)\end{array}$ & $\begin{array}{c}0.363 \\
(0.222)\end{array}$ \\
\hline MENA dummy & & & $\begin{array}{c}0.825^{* * *} \\
(0.201)\end{array}$ & $\begin{array}{c}0.810^{* * *} \\
(0.201)\end{array}$ \\
\hline Constant & $\begin{array}{c}12.27^{* * *} \\
(1.058)\end{array}$ & $\begin{array}{c}12.85^{* * *} \\
(1.100)\end{array}$ & $\begin{array}{c}12.13^{* * *} \\
(1.371)\end{array}$ & $\begin{array}{c}12.19^{* * *} \\
(1.373)\end{array}$ \\
\hline Estimator & Logit & Logit & Logit & Logit \\
\hline Year Fixed Effects & Yes & Yes & Yes & Yes \\
\hline MDBs Fixed Effects & No & No & Yes & Yes \\
\hline Number of MDBs & 16 & 16 & 10 & 10 \\
\hline Number of countries & 119 & 119 & 119 & 119 \\
\hline Total Observations & 6,074 & 6,074 & 6,067 & 6,067 \\
\hline
\end{tabular}

Note:

(1) Standard errors in parenthesis.

(2) Statistical significance: ${ }^{* *} p<0.01,{ }^{* *} p<0.05,{ }^{*} p<0.1$ 
Robustness Table A2: Influence of BRI initiative on US voting patterns in MDBs:

Ordered Logit estimations

\begin{tabular}{|c|c|c|c|}
\hline & $\begin{array}{c}(1) \\
\text { Yes vote }\end{array}$ & $\begin{array}{c}\text { (2) } \\
\text { Yes vote }\end{array}$ & $\begin{array}{c}(3) \\
\text { Yes vote }\end{array}$ \\
\hline Belt Road initiative membership & $\begin{array}{c}0.790^{* * *} \\
(0.102)\end{array}$ & $\begin{array}{c}0.612^{* * *} \\
(0.127)\end{array}$ & $\begin{array}{c}0.377^{* * *} \\
(0.119)\end{array}$ \\
\hline Belt Road initiative membership X Chinese Aid/DAC Aid & & & $\begin{array}{l}0.00349 \\
(0.0199)\end{array}$ \\
\hline Chinese Aid/DAC Aid & & & $\begin{array}{c}-0.0677^{* * *} \\
(0.0166)\end{array}$ \\
\hline Per capita GDP $(\log )$ & $\begin{array}{c}-0.676^{* * *} \\
(0.0702)\end{array}$ & $\begin{array}{c}-0.792^{* * *} \\
(0.0820)\end{array}$ & $\begin{array}{c}-0.301^{* * *} \\
(0.0826)\end{array}$ \\
\hline Population (log) & $\begin{array}{c}-0.429^{* * *} \\
(0.0496)\end{array}$ & $\begin{array}{c}-0.282^{* * *} \\
(0.0644)\end{array}$ & $\begin{array}{c}-0.147^{* * *} \\
(0.0557)\end{array}$ \\
\hline Democracy Polity index & $\begin{array}{l}0.0618^{\star * *} \\
(0.00700)\end{array}$ & $\begin{array}{l}0.0764^{\star * *} \\
(0.00859)\end{array}$ & $\begin{array}{c}0.00834 \\
(0.00922)\end{array}$ \\
\hline US Exports (log) & $\begin{array}{l}0.251^{* * *} \\
(0.0379)\end{array}$ & $\begin{array}{l}0.167^{* * *} \\
(0.0542)\end{array}$ & $\begin{array}{l}0.155^{* * *} \\
(0.0413)\end{array}$ \\
\hline UNGA Voting alignment index & $\begin{array}{c}1.002^{* * *} \\
(0.303)\end{array}$ & $\begin{array}{c}0.538 \\
(0.339)\end{array}$ & $\begin{array}{c}0.722^{* *} \\
(0.324)\end{array}$ \\
\hline US Aid (log) & $\begin{array}{c}-0.0345^{* * *} \\
(0.00765)\end{array}$ & $\begin{array}{c}-0.0266^{* * *} \\
(0.00807)\end{array}$ & $\begin{array}{l}-0.0172^{* *} \\
(0.00819)\end{array}$ \\
\hline Civil conflict & $\begin{array}{l}0.254^{* *} \\
(0.104)\end{array}$ & $\begin{array}{c}0.152 \\
(0.114)\end{array}$ & $\begin{array}{c}-0.181 \\
(0.114)\end{array}$ \\
\hline East Asia dummy & & $\begin{array}{c}0.246 \\
(0.150)\end{array}$ & \\
\hline South Asia dummy & & $\begin{array}{l}-0.0365 \\
(0.173)\end{array}$ & \\
\hline Europe \& Central Asia dummy & & $\begin{array}{c}0.932^{* * *} \\
(0.181)\end{array}$ & \\
\hline Latin America \& Caribbean dummy & & $\begin{array}{c}0.761^{* * *} \\
(0.183)\end{array}$ & \\
\hline MENA dummy & & $\begin{array}{c}0.960^{* * *} \\
(0.199)\end{array}$ & \\
\hline Estimator & OLogit & OLogit & OLogit \\
\hline Year Fixed Effects & Yes & Yes & Yes \\
\hline MDBs Fixed Effects & No & No & No \\
\hline Number of MDBs & 16 & 16 & 16 \\
\hline Number of countries & 119 & 119 & 102 \\
\hline Total Observations & 6,074 & 6,074 & 5,317 \\
\hline
\end{tabular}

Note:

(1) Standard errors in parenthesis.

(2) Statistical significance: ${ }^{* *} p<0.01,{ }^{* *} p<0.05,{ }^{*} p<0.1$ 
Robustness Table A3: Influence of BRI initiative on US voting patterns in MDBs:

OLS estimations

\begin{tabular}{|c|c|c|c|}
\hline & $\begin{array}{c}(1) \\
\text { Yes vote }\end{array}$ & $\begin{array}{c}(2) \\
\text { Yes vote }\end{array}$ & $\begin{array}{c}(3) \\
\text { Yes vote } \\
\end{array}$ \\
\hline \multirow[t]{2}{*}{ Belt Road initiative membership } & $0.102^{* * *}$ & $0.0900^{* * *}$ & $0.0377^{* * *}$ \\
\hline & $(0.0118)$ & $(0.0150)$ & $(0.0125)$ \\
\hline \multirow[t]{2}{*}{ Belt Road initiative membership X Chinese Aid/DAC Aid } & & & 0.00177 \\
\hline & & & $(0.00375)$ \\
\hline \multirow[t]{2}{*}{ Chinese Aid/DAC Aid } & & & $-0.0146^{* * *}$ \\
\hline & & & $(0.00268)$ \\
\hline \multirow[t]{2}{*}{ Per capita GDP (log) } & $-0.0819 * * *$ & $-0.0954^{* * *}$ & $-0.0302^{* * *}$ \\
\hline & $(0.00735)$ & $(0.00874)$ & $(0.00841)$ \\
\hline \multirow[t]{2}{*}{ Population (log) } & $-0.0520^{* * *}$ & $-0.0306^{* * *}$ & $-0.0140 * * *$ \\
\hline & $(0.00489)$ & $(0.00652)$ & $(0.00535)$ \\
\hline \multirow[t]{2}{*}{ Democracy Polity index } & $0.00960 * * *$ & $0.0110^{* * *}$ & 0.000680 \\
\hline & $(0.000978)$ & $(0.00111)$ & $(0.00101)$ \\
\hline \multirow[t]{2}{*}{ US Exports (log) } & $0.0274^{* * *}$ & $0.0156^{* * *}$ & $0.0160^{* * *}$ \\
\hline & $(0.00368)$ & $(0.00554)$ & $(0.00412)$ \\
\hline \multirow[t]{2}{*}{ UNGA Voting alignment index } & $0.123^{* * *}$ & $0.0755^{* *}$ & $0.0796^{* *}$ \\
\hline & $(0.0333)$ & $(0.0347)$ & $(0.0349)$ \\
\hline \multirow[t]{2}{*}{ US Aid (log) } & $-0.00426^{* * *}$ & $-0.00358^{* * *}$ & $-0.00208^{* * *}$ \\
\hline & $(0.000773)$ & $(0.000778)$ & $(0.000785)$ \\
\hline \multirow[t]{2}{*}{ Civil conflict } & $0.0536^{* \star *}$ & $0.0390^{* * *}$ & -0.0199 \\
\hline & $(0.0125)$ & $(0.0130)$ & $(0.0125)$ \\
\hline \multirow[t]{2}{*}{ East Asia dummy } & & 0.0121 & \\
\hline & & $(0.0227)$ & \\
\hline \multirow[t]{2}{*}{ South Asia dummy } & & 0.0138 & \\
\hline & & $(0.0220)$ & \\
\hline \multirow[t]{2}{*}{ Europe \& Central Asia dummy } & & $0.116^{* * *}$ & \\
\hline & & $(0.0235)$ & \\
\hline \multirow[t]{2}{*}{ Latin America \& Caribbean dummy } & & $0.113^{* * *}$ & \\
\hline & & $(0.0271)$ & \\
\hline \multirow[t]{2}{*}{ MENA dummy } & & $0.146^{* * *}$ & \\
\hline & & $(0.0275)$ & \\
\hline \multirow[t]{2}{*}{ Constant } & $2.194^{* * *}$ & $1.948^{* * *}$ & $1.283^{* * *}$ \\
\hline & $(0.106)$ & $(0.132)$ & $(0.117)$ \\
\hline Estimator & OLS & OLS & OLS \\
\hline Year Fixed Effects & Yes & Yes & Yes \\
\hline MDBs Fixed Effects & No & No & No \\
\hline Number of MDBs & 16 & 16 & 16 \\
\hline Number of countries & 119 & 119 & 102 \\
\hline Total Observations & 6,074 & 6,074 & 5,317 \\
\hline
\end{tabular}

Note:

(1) Standard errors in parenthesis.

(2) Statistical significance: ${ }^{* *} p<0.01,{ }^{* *} p<0.05,{ }^{*} p<0.1$ 
Robustness Table A4: Influence of BRI initiative on US voting patterns in MDBs: Multinomial estimations

\begin{tabular}{|c|c|c|}
\hline & $\begin{array}{c}\text { (1) } \\
\text { Abstain }\end{array}$ & $\begin{array}{c}\text { (2) } \\
\text { Abstain }\end{array}$ \\
\hline Belt Road initiative membership & $\begin{array}{l}-0.283 \\
(0.278)\end{array}$ & $\begin{array}{l}0.752^{*} \\
(0.443)\end{array}$ \\
\hline Per capita GDP (log) & $\begin{array}{l}1.570^{* * *} \\
(0.175)\end{array}$ & $\begin{array}{l}3.006^{* * *} \\
(0.441)\end{array}$ \\
\hline Population (log) & $\begin{array}{l}0.791 \text { *** } \\
(0.112)\end{array}$ & $\begin{array}{l}1.526 * * * \\
(0.305)\end{array}$ \\
\hline Democracy Polity index & $\begin{array}{l}0.0582^{* * *} \\
(0.0167)\end{array}$ & $\begin{array}{c}-0.0534^{* *} \\
(0.0263)\end{array}$ \\
\hline US Exports (log) & $\begin{array}{c}-0.628^{* * *} \\
(0.0721)\end{array}$ & $\begin{array}{l}-1.283^{* * *} \\
(0.228)\end{array}$ \\
\hline UNGA Voting alignment index & $\begin{array}{l}-1.432 \\
(0.970)\end{array}$ & $\begin{array}{l}-0.797 \\
(1.088)\end{array}$ \\
\hline US Aid (log) & $\begin{array}{l}0.100^{* * *} \\
(0.0166)\end{array}$ & $\begin{array}{l}0.182^{* * *} \\
(0.0336)\end{array}$ \\
\hline Civil conflict & $\begin{array}{c}-1.530^{* * *} \\
(0.378)\end{array}$ & $\begin{array}{c}-1.555^{* * *} \\
(0.410)\end{array}$ \\
\hline East Asia dummy & & $\begin{array}{c}-3.176^{* * *} \\
(0.689)\end{array}$ \\
\hline South Asia dummy & & $\begin{array}{l}-0.309 \\
(0.474)\end{array}$ \\
\hline Europe \& Central Asia dummy & & $\begin{array}{c}-4.001^{* * *} \\
(0.868)\end{array}$ \\
\hline Latin America \& Caribbean dummy & & $\begin{array}{l}0.948^{*} \\
(0.508)\end{array}$ \\
\hline MENA dummy & & $\begin{array}{l}-2.406 * * \\
(1.024)\end{array}$ \\
\hline Constant & $\begin{array}{c}-27.00^{* * *} \\
(2.870)\end{array}$ & $\begin{array}{c}-47.24^{* * *} \\
(7.569)\end{array}$ \\
\hline & $\begin{array}{c}\text { (1) } \\
\text { No vote }\end{array}$ & $\begin{array}{c}\text { (2) } \\
\text { No vote }\end{array}$ \\
\hline Belt Road initiative membership & $\begin{array}{c}-0.828^{* * *} \\
(0.108)\end{array}$ & $\begin{array}{c}-0.720^{* * *} \\
(0.135)\end{array}$ \\
\hline Per capita GDP (log) & $\begin{array}{l}0.559 * * * \\
(0.0742)\end{array}$ & $\begin{array}{l}0.602^{* * *} \\
(0.0843)\end{array}$ \\
\hline Population (log) & $\begin{array}{l}0.384^{* * *} \\
(0.0519)\end{array}$ & $\begin{array}{l}0.191^{* * *} \\
(0.0661)\end{array}$ \\
\hline Democracy Polity index & $\begin{array}{l}-0.0728^{* * *} \\
(0.00754)\end{array}$ & $\begin{array}{r}-0.0757^{* * *} \\
(0.00908)\end{array}$ \\
\hline US Exports (log) & $\begin{array}{l}-0.201^{* * *} \\
(0.0406)\end{array}$ & $\begin{array}{l}-0.0718 \\
(0.0569)\end{array}$ \\
\hline UNGA Voting alignment index & $\begin{array}{c}-0.973^{* * *} \\
(0.324)\end{array}$ & $\begin{array}{l}-0.634^{*} \\
(0.362)\end{array}$ \\
\hline US Aid (log) & $\begin{array}{l}0.0253 * * * \\
(0.00810)\end{array}$ & $\begin{array}{c}0.0145 * \\
(0.00842)\end{array}$ \\
\hline Civil conflict & $\begin{array}{l}-0.135 \\
(0.108)\end{array}$ & $\begin{array}{c}-0.0574 \\
(0.119)\end{array}$ \\
\hline East Asia dummy & & $\begin{array}{l}-0.116 \\
(0.159)\end{array}$ \\
\hline South Asia dummy & & $\begin{array}{c}-0.00741 \\
(0.196)\end{array}$ \\
\hline Europe \& Central Asia dummy & & $\begin{array}{c}-0.670^{* * *} \\
(0.189)\end{array}$ \\
\hline Latin America \& Caribbean dummy & & $\begin{array}{c}-0.935^{* * *} \\
(0.200)\end{array}$ \\
\hline MENA dummy & & $\begin{array}{c}-0.864^{* * *} \\
(0.202)\end{array}$ \\
\hline Constant & $\begin{array}{c}-11.61^{* * *} \\
(1.131)\end{array}$ & $\begin{array}{c}-9.016^{* * *} \\
(1.311)\end{array}$ \\
\hline Estimator & MLogit & MLogit \\
\hline Year Fixed Effects & Yes & Yes \\
\hline MDBs Fixed Effects & No & No \\
\hline Number of MDBs & 16 & 16 \\
\hline Number of countries & 119 & 119 \\
\hline Total Observations & 6,074 & 6,074 \\
\hline
\end{tabular}

Note:

(1) Standard errors in parenthesis.

(2) Statistical significance: ${ }^{* * *} p<0.01,{ }^{* *} p<0.05,{ }^{*} p<0.1$ 
Robustness Table A5: Influence of BRI initiative on US voting patterns in MDBs:

Alternative Interaction variables

\begin{tabular}{|c|c|c|}
\hline & $\begin{array}{c}(1) \\
\text { Yes vote }\end{array}$ & $\begin{array}{c}(2) \\
\text { Yes vote }\end{array}$ \\
\hline Belt Road initiative membership & $\begin{array}{c}0.471^{* * *} \\
(0.125)\end{array}$ & $\begin{array}{c}0.161 \\
(0.169)\end{array}$ \\
\hline Belt Road initiative membership X Chinese Aid/GDP & $\begin{array}{l}-0.276 \\
(0.599)\end{array}$ & $\begin{array}{l}-0.593 \\
(0.625)\end{array}$ \\
\hline Chinese Aid/GDP & $\begin{array}{c}-1.000^{* * *} \\
(0.383)\end{array}$ & $\begin{array}{c}-1.588^{* * *} \\
(0.456)\end{array}$ \\
\hline Per capita GDP (log) & $\begin{array}{l}-0.548^{* * *} \\
(0.0792)\end{array}$ & $\begin{array}{c}-0.672 * * * \\
(0.0859)\end{array}$ \\
\hline Population (log) & $\begin{array}{c}-0.246^{* * *} \\
(0.0558)\end{array}$ & $\begin{array}{l}-0.129 * \\
(0.0690)\end{array}$ \\
\hline Democracy Polity index & $\begin{array}{c}0.0140 \\
(0.00876)\end{array}$ & $\begin{array}{c}0.0324^{* * *} \\
(0.0105)\end{array}$ \\
\hline US Exports (log) & $\begin{array}{l}0.223^{* * *} \\
(0.0406)\end{array}$ & $\begin{array}{l}0.138^{* *} \\
(0.0570)\end{array}$ \\
\hline UNGA Voting alignment index & $\begin{array}{l}0.623^{*} \\
(0.325)\end{array}$ & $\begin{array}{c}0.267 \\
(0.354)\end{array}$ \\
\hline US Aid (log) & $\begin{array}{l}-0.0272^{* * *} \\
(0.00810)\end{array}$ & $\begin{array}{c}-0.0236^{* * *} \\
(0.00820)\end{array}$ \\
\hline Civil conflict & $\begin{array}{c}-0.0481 \\
(0.110)\end{array}$ & $\begin{array}{c}-0.0188 \\
(0.119)\end{array}$ \\
\hline East Asia dummy & & $\begin{array}{c}1.356^{* * *} \\
(0.239)\end{array}$ \\
\hline South Asia dummy & & $\begin{array}{l}0.0280 \\
(0.201)\end{array}$ \\
\hline Europe \& Central Asia dummy & & $\begin{array}{c}1.053^{* * *} \\
(0.186)\end{array}$ \\
\hline Latin America \& Caribbean dummy & & $\begin{array}{c}0.706^{* * *} \\
(0.191)\end{array}$ \\
\hline MENA dummy & & $\begin{array}{c}0.744^{* * *} \\
(0.201)\end{array}$ \\
\hline Constant & $\begin{array}{c}9.335^{* * *} \\
(1.257)\end{array}$ & $\begin{array}{c}8.339 * * * \\
(1.407)\end{array}$ \\
\hline Estimator & OLS & OLS \\
\hline Year Fixed Effects & Yes & Yes \\
\hline MDBs Fixed Effects & No & No \\
\hline Number of MDBs & 16 & 16 \\
\hline Number of countries & 102 & 102 \\
\hline Total Observations & 5,319 & 5,319 \\
\hline
\end{tabular}

Note:

(1) Standard errors in parenthesis.

(2) Statistical significance: ${ }^{* *} p<0.01,{ }^{* *} p<0.05,{ }^{*} p<0.1$ 
Robustness Table A6: Influence of BRI initiative on US voting patterns in

MDBs:

Kitchen sink approach

\begin{tabular}{|c|c|c|c|c|}
\hline & $\begin{array}{c}\text { (1) } \\
\text { Yes vote }\end{array}$ & $\begin{array}{c}(2) \\
\text { Yes vote } \\
\end{array}$ & $\begin{array}{c}(3) \\
\text { Yes vote }\end{array}$ & $\begin{array}{c}(4) \\
\text { Yes vote } \\
\end{array}$ \\
\hline Belt Road initiative membership & $\begin{array}{c}0.713^{* * * *} \\
(0.125)\end{array}$ & $\begin{array}{c}0.520^{* * * *} \\
(0.149)\end{array}$ & $\begin{array}{c}0.520^{* * * *} \\
(0.149)\end{array}$ & $\begin{array}{l}0.0150 \\
(0.179)\end{array}$ \\
\hline Belt Road initiative membership $\mathbf{X}$ Chinese Aid/DAC Aid & & & $\begin{array}{l}0.113^{* * *} \\
(0.0408)\end{array}$ & $\begin{array}{l}0.113^{* * *} \\
(0.0408)\end{array}$ \\
\hline Chinese Aid/DAC Aid & & & & $\begin{array}{c}-0.169^{* * *} \\
(0.0280)\end{array}$ \\
\hline Per capita GDP (log) & $\begin{array}{c}-0.743^{* * *} \\
(0.0889)\end{array}$ & $\begin{array}{c}-0.898^{* * *} \\
(0.101)\end{array}$ & $\begin{array}{c}-0.898^{* * * *} \\
(0.101)\end{array}$ & $\begin{array}{c}-0.500^{* * *} \\
(0.110)\end{array}$ \\
\hline Population (log) & $\begin{array}{c}-0.436^{* * *} \\
(0.0617)\end{array}$ & $\begin{array}{l}-0.238^{* * *} \\
(0.0737)\end{array}$ & $\begin{array}{l}-0.238^{* * *} \\
(0.0737)\end{array}$ & $\begin{array}{c}0.0519 \\
(0.0801)\end{array}$ \\
\hline Democracy Polity index & $\begin{array}{l}0.0572^{* * *} \\
(0.00815)\end{array}$ & $\begin{array}{c}0.0729^{* * * *} \\
(0.0100)\end{array}$ & $\begin{array}{c}0.0729^{* * * *} \\
(0.0100)\end{array}$ & $\begin{array}{l}0.0271^{* * *} \\
(0.0122)\end{array}$ \\
\hline US Exports (log) & $\begin{array}{l}0.244^{* * *} \\
(0.0427)\end{array}$ & $\begin{array}{c}0.104^{*} \\
(0.0596)\end{array}$ & $\begin{array}{c}0.104^{*} \\
(0.0596)\end{array}$ & $\begin{array}{l}0.00848 \\
(0.0613)\end{array}$ \\
\hline UNGA Voting alignment index & $\begin{array}{c}0.413 \\
(0.381)\end{array}$ & $\begin{array}{l}-0.213 \\
(0.406)\end{array}$ & $\begin{array}{l}-0.213 \\
(0.406)\end{array}$ & $\begin{array}{c}0.153 \\
(0.441)\end{array}$ \\
\hline US Aid $(\log )$ & $\begin{array}{c}-0.0452^{* * *} \\
(0.00880)\end{array}$ & $\begin{array}{c}-0.0319^{* * *} \\
(0.00918)\end{array}$ & $\begin{array}{c}-0.0319^{* * *} \\
(0.00918)\end{array}$ & $\begin{array}{l}-0.00738 \\
(0.00928)\end{array}$ \\
\hline Civil conflict & $\begin{array}{l}0.0318 \\
(0.128)\end{array}$ & $\begin{array}{l}0.0248 \\
(0.133)\end{array}$ & $\begin{array}{l}0.0248 \\
(0.133)\end{array}$ & $\begin{array}{l}-0.151 \\
(0.141)\end{array}$ \\
\hline US Sanctions & $\begin{array}{l}1.131^{* * *} \\
(0.393)\end{array}$ & $\begin{array}{l}0.805^{* *} \\
(0.388)\end{array}$ & $\begin{array}{l}0.805^{* *} \\
(0.388)\end{array}$ & $\begin{array}{l}0.892^{* *} \\
(0.379)\end{array}$ \\
\hline Egypt dummy & $\begin{array}{c}1.161^{* * *} \\
(0.355)\end{array}$ & $\begin{array}{l}0.712^{*} \\
(0.408)\end{array}$ & $\begin{array}{l}0.712^{*} \\
(0.408)\end{array}$ & $\begin{array}{c}0.427 \\
(0.410)\end{array}$ \\
\hline US Military Alliance & $\begin{array}{c}0.662^{* * *} \\
(0.238)\end{array}$ & $\begin{array}{c}0.823^{* * *} \\
(0.244)\end{array}$ & $\begin{array}{c}0.823^{* * *} \\
(0.244)\end{array}$ & $\begin{array}{l}0.731^{* *} \\
(0.328)\end{array}$ \\
\hline Economic Freedom Index & $\begin{array}{l}0.0262^{* * * *} \\
(0.00799)\end{array}$ & $\begin{array}{l}0.0296^{* * * *} \\
(0.00816)\end{array}$ & $\begin{array}{l}0.0296^{* * * *} \\
(0.00816)\end{array}$ & $\begin{array}{l}-0.00657 \\
(0.00970)\end{array}$ \\
\hline PTS Human Rights index & $\begin{array}{c}0.0181 \\
(0.0752)\end{array}$ & $\begin{array}{c}0.0815 \\
(0.0766)\end{array}$ & $\begin{array}{c}0.0815 \\
(0.0766)\end{array}$ & $\begin{array}{l}0.00705 \\
(0.0775)\end{array}$ \\
\hline State Failure Index & $\begin{array}{l}0.000817 \\
(0.00568)\end{array}$ & $\begin{array}{c}0.00430 \\
(0.00580)\end{array}$ & $\begin{array}{c}0.00430 \\
(0.00580)\end{array}$ & $\begin{array}{l}-0.00516 \\
(0.00631)\end{array}$ \\
\hline Coup d'état & $\begin{array}{c}0.491 \\
(0.360)\end{array}$ & $\begin{array}{c}0.335 \\
(0.359)\end{array}$ & $\begin{array}{c}0.335 \\
(0.359)\end{array}$ & $\begin{array}{l}0.0897 \\
(0.402)\end{array}$ \\
\hline Christian dummy & $\begin{array}{c}0.00256 \\
(0.123)\end{array}$ & $\begin{array}{c}-0.0281 \\
(0.147)\end{array}$ & $\begin{array}{c}-0.0281 \\
(0.147)\end{array}$ & $\begin{array}{l}-0.104 \\
(0.147)\end{array}$ \\
\hline East Asia dummy & & $\begin{array}{c}0.546^{* * *} \\
(0.180)\end{array}$ & $\begin{array}{c}0.546^{* * * *} \\
(0.180)\end{array}$ & $\begin{array}{c}1.131^{* * *} \\
(0.229)\end{array}$ \\
\hline South Asia dummy & & $\begin{array}{l}-0.118 \\
(0.210)\end{array}$ & $\begin{array}{l}-0.118 \\
(0.210)\end{array}$ & $\begin{array}{l}-0.0721 \\
(0.228)\end{array}$ \\
\hline Europe \& Central Asia dummy & & $\begin{array}{l}1.294^{* * * *} \\
(0.242)\end{array}$ & $\begin{array}{l}1.294^{* * * *} \\
(0.242)\end{array}$ & $\begin{array}{l}1.163^{* * * *} \\
(0.235)\end{array}$ \\
\hline Latin America \& Caribbean dummy & & $\begin{array}{c}1.274^{* * *} \\
(0.214)\end{array}$ & $\begin{array}{c}1.274^{* * *} \\
(0.214)\end{array}$ & $\begin{array}{c}1.533^{* * * *} \\
(0.230)\end{array}$ \\
\hline MENA dummy & & $\begin{array}{c}0.926^{* * *} \\
(0.263)\end{array}$ & $\begin{array}{l}0.926^{* * *} \\
(0.263)\end{array}$ & $\begin{array}{c}0.735^{* * *} \\
(0.275)\end{array}$ \\
\hline Constant & $\begin{array}{c}11.83^{* * * *} \\
(1.587)\end{array}$ & $\begin{array}{c}9.008^{* * *} \\
(1.713)\end{array}$ & $\begin{array}{c}9.008^{* * * *} \\
(1.713)\end{array}$ & $\begin{array}{l}4.602^{* * *} \\
(1.916) \\
\end{array}$ \\
\hline Estimator & Logit & Logit & Logit & Logit \\
\hline Year Fixed Effects & Yes & Yes & Yes & Yes \\
\hline MDBs Fixed Effects & No & No & No & No \\
\hline Number of MDBs & 16 & 16 & 16 & 16 \\
\hline Number of countries & 101 & 101 & 101 & 85 \\
\hline Total Observations & 5,607 & 5,607 & 5,607 & 4,896 \\
\hline
\end{tabular}

Note:

(1) Standard errors in parenthesis.

(2) Statistical significance: ${ }^{* *} p<0.01,{ }^{* *} p<0.05,{ }^{*} p<0.1$ 
Robustness Table A7: Influence of BRI initiative on US voting patterns in MDBs:

2SLS-IV estimations

\begin{tabular}{lcc}
\hline & $\begin{array}{c}(\mathbf{1}) \\
\text { Yes vote }\end{array}$ & $\begin{array}{c}(\mathbf{2}) \\
\text { Yes vote }\end{array}$ \\
\hline Belt Road Initiative membership & $0.611^{* *}$ & $0.456^{*}$ \\
& $(0.297)$ & $(0.238)$ \\
Per capita GDP (log) & $-0.172^{* * *}$ & $-0.125^{* * *}$ \\
& $(0.0595)$ & $(0.0322)$ \\
Population (log) & $-0.101^{* *}$ & $-0.0616^{* * *}$ \\
& $(0.0409)$ & $(0.0237)$ \\
Democracy Polity index & $0.00955^{* *}$ & $0.00617^{* * *}$ \\
& $(0.00384)$ & $(0.00203)$ \\
US Exports (log) & $0.0819^{* * *}$ & $0.0517^{* * *}$ \\
& $(0.0298)$ & $(0.0166)$ \\
UNGA Voting alignment index & $0.169^{* * *}$ & $0.136^{* *}$ \\
& $(0.0630)$ & $(0.0573)$ \\
US Aid (log) & $-0.00964^{* *}$ & $-0.00671^{* * *}$ \\
Civil conflict & $(0.00379)$ & $(0.00243)$ \\
Constant & -0.0135 & -0.00532 \\
& $(0.0158)$ & $(0.0139)$ \\
\hline Estimator & $3.469^{* * *}$ & $2.468^{* * *}$ \\
Year Fixed Effects & $(0.990)$ & $(0.489)$ \\
Joint F-statistics & $2 S \mathrm{SS}-\mathrm{IV}$ & $2 \mathrm{SLS}-\mathrm{IV}$ \\
MDBs Fixed Effects & Yes & Yes \\
Number of MDBs & $12.46^{* * *}$ & $19.57^{* * *}$ \\
Number of countries & No & Yes \\
Total Observations & 16 & 10 \\
& 102 & 102 \\
& 5,319 & 5,319 \\
\hline & & \\
& &
\end{tabular}

Note:

(1) Standard errors in parenthesis.

(2) Statistical significance: ${ }^{* * *} p<0.01,{ }^{* *} p<0.05,{ }^{*} p<0.1$ 
Robustness Table A8: Influence of BRI initiative on US voting patterns in MDBs:

Drop insignificant variables

\begin{tabular}{|c|c|c|c|c|}
\hline & $\begin{array}{c}\text { (1) } \\
\text { Yes vote }\end{array}$ & $\begin{array}{c}\text { (2) } \\
\text { Yes vote }\end{array}$ & $\begin{array}{c}(3) \\
\text { Yes vote }\end{array}$ & $\begin{array}{c}(4) \\
\text { Yes vote }\end{array}$ \\
\hline Belt Road initiative membership & $\begin{array}{c}0.590^{* * *} \\
(0.127)\end{array}$ & $\begin{array}{c}0.536^{* * *} \\
(0.129)\end{array}$ & $\begin{array}{c}3.402^{* * *} \\
(0.290)\end{array}$ & $\begin{array}{c}3.393^{* * *} \\
(0.287)\end{array}$ \\
\hline Per capita GDP (log) & $\begin{array}{c}-0.844^{* * *} \\
(0.0847)\end{array}$ & $\begin{array}{c}-0.853^{* * *} \\
(0.0858)\end{array}$ & $\begin{array}{l}-0.221^{* *} \\
(0.0880)\end{array}$ & $\begin{array}{c}-0.221^{* * *} \\
(0.0836)\end{array}$ \\
\hline Population (log) & $\begin{array}{c}-0.297^{* * *} \\
(0.0638)\end{array}$ & $\begin{array}{c}-0.287^{* * *} \\
(0.0645)\end{array}$ & $\begin{array}{c}-0.0429^{*} \\
(0.0252)\end{array}$ & $\begin{array}{c}-0.0418^{*} \\
(0.0237)\end{array}$ \\
\hline Democracy Polity index & $\begin{array}{l}0.0828^{* * *} \\
(0.00804)\end{array}$ & $\begin{array}{l}0.0831^{* * *} \\
(0.00809)\end{array}$ & $\begin{array}{l}0.0390^{* * *} \\
(0.00529)\end{array}$ & $\begin{array}{l}0.0386^{* * *} \\
(0.00512)\end{array}$ \\
\hline US Exports (log) & $\begin{array}{l}0.197^{* * *} \\
(0.0541)\end{array}$ & $\begin{array}{l}0.194^{* * *} \\
(0.0547)\end{array}$ & $\begin{array}{c}0.0449 \\
(0.0283)\end{array}$ & $\begin{array}{l}0.0467^{*} \\
(0.0260)\end{array}$ \\
\hline US Aid (log) & $\begin{array}{c}-0.0261^{* * *} \\
(0.00805)\end{array}$ & $\begin{array}{c}-0.0281^{* * *} \\
(0.00824)\end{array}$ & $\begin{array}{c}-0.0214^{* * *} \\
(0.00251)\end{array}$ & $\begin{array}{c}-0.0214^{* * *} \\
(0.00252)\end{array}$ \\
\hline East Asia dummy & $\begin{array}{l}0.246^{*} \\
(0.143)\end{array}$ & $\begin{array}{l}0.0727 \\
(0.164)\end{array}$ & $\begin{array}{c}-1.411^{* * *} \\
(0.303)\end{array}$ & $\begin{array}{c}-1.348^{* * *} \\
(0.275)\end{array}$ \\
\hline South Asia dummy & $\begin{array}{l}-0.104 \\
(0.175)\end{array}$ & $\begin{array}{l}-0.261 \\
(0.192)\end{array}$ & $\begin{array}{c}-2.470^{* * *} \\
(0.241)\end{array}$ & $\begin{array}{c}-2.416^{* * *} \\
(0.221)\end{array}$ \\
\hline Europe \& Central Asia dummy & $\begin{array}{c}1.134^{* * *} \\
(0.177)\end{array}$ & $\begin{array}{c}0.708^{* * *} \\
(0.193)\end{array}$ & $\begin{array}{c}-1.786^{* * *} \\
(0.344)\end{array}$ & $\begin{array}{c}-1.671^{* * *} \\
(0.275)\end{array}$ \\
\hline Latin America \& Caribbean dummy & $\begin{array}{c}0.763^{* * *} \\
(0.186)\end{array}$ & $\begin{array}{c}0.346 \\
(0.219)\end{array}$ & $\begin{array}{l}-0.0334 \\
(0.128)\end{array}$ & $\begin{array}{l}-0.0381 \\
(0.0836)\end{array}$ \\
\hline MENA dummy & $\begin{array}{c}1.011^{* * *} \\
(0.196)\end{array}$ & $\begin{array}{c}0.790^{* * *} \\
(0.200)\end{array}$ & $\begin{array}{c}-0.591^{* * *} \\
(0.204)\end{array}$ & $\begin{array}{c}-0.527^{* * *} \\
(0.167)\end{array}$ \\
\hline Constant & $\begin{array}{c}11.93^{* * *} \\
(1.327)\end{array}$ & $\begin{array}{c}12.06^{* * *} \\
(1.349)\end{array}$ & $\begin{array}{c}3.454^{* * *} \\
(0.998) \\
\end{array}$ & $\begin{array}{c}3.293^{* * *} \\
(0.929) \\
\end{array}$ \\
\hline Estimator & Logit & Logit & Logit & Logit \\
\hline Year Fixed Effects & Yes & Yes & Yes & Yes \\
\hline MDBs Fixed Effects & No & No & Yes & Yes \\
\hline Number of MDBs & 16 & 16 & 10 & 10 \\
\hline Number of countries & 119 & 119 & 119 & 119 \\
\hline Total Observations & 6,158 & 6,151 & 5,379 & 5,372 \\
\hline
\end{tabular}

Note:

(1) Standard errors in parenthesis.

(2) Statistical significance: ${ }^{* * *} p<0.01,{ }^{* *} p<0.05,{ }^{*} p<0.1$ 